\title{
Structure and evolution of the drainage system of a Himalayan debris-covered glacier, and its relationship with patterns of mass loss
}

\author{
Douglas I. Benn ${ }^{1}$, Sarah Thompson ${ }^{2}$, Jason Gulley ${ }^{3}$, Jordan Mertes ${ }^{4}$, Adrian Luckman ${ }^{2}$, and Lindsey Nicholson ${ }^{5}$ \\ ${ }^{1}$ School of Geography and Sustainable Development, University of St Andrews, St Andrews, UK \\ ${ }^{2}$ Department of Geography, Swansea University, Swansea, UK \\ ${ }^{3}$ School of Geosciences, University of South Florida, Tampa, FL, USA \\ ${ }^{4}$ Department of Geological and Mining Engineering and Sciences, Michigan Tech, Houghton, MI, USA \\ ${ }^{5}$ Institute for Atmospheric and Cryospheric Sciences, University of Innsbruck, Innsbruck, Austria
}

Correspondence to: Doug I. Benn (dib2@st-andrews.ac.uk)

Received: 28 February 2017 - Discussion started: 14 March 2017

Revised: 27 June 2017 - Accepted: 11 July 2017 - Published: 22 September 2017

\begin{abstract}
We provide the first synoptic view of the drainage system of a Himalayan debris-covered glacier and its evolution through time, based on speleological exploration and satellite image analysis of Ngozumpa Glacier, Nepal. The drainage system has several linked components: (1) a seasonal subglacial drainage system below the upper ablation zone; (2) supraglacial channels, allowing efficient meltwater transport across parts of the upper ablation zone; (3) submarginal channels, allowing long-distance transport of meltwater; (4) perched ponds, which intermittently store meltwater prior to evacuation via the englacial drainage system; (5) englacial cut-and-closure conduits, which may undergo repeated cycles of abandonment and reactivation; and (6) a "base-level" lake system (Spillway Lake) dammed behind the terminal moraine. The distribution and relative importance of these elements has evolved through time, in response to sustained negative mass balance. The area occupied by perched ponds has expanded upglacier at the expense of supraglacial channels, and Spillway Lake has grown as more of the glacier surface ablates to base level. Subsurface processes play a governing role in creating, maintaining, and shutting down exposures of ice at the glacier surface, with a major impact on spatial patterns and rates of surface mass loss. Comparison of our results with observations on other glaciers indicate that englacial drainage systems play a key role in the response of debris-covered glaciers to sustained periods of negative mass balance.
\end{abstract}

\section{Introduction}

Debris-covered glaciers in many parts of the Himalaya have undergone significant surface lowering in recent times (Kääb et al., 2012), with net losses of several tens of metres since the 1970s (Bolch et al., 2008a, 2011). Glacier thinning and reduced surface gradients have resulted in lower driving stresses and ice velocities, and large parts of many glaciers are now stagnant or nearly so (Bolch et al., 2008b; Quincey et al., 2009). These morphological and dynamic changes have encouraged formation of supraglacial ponds and lakes and increased water storage within glacial hydrological systems (Quincey et al., 2007; Benn et al., 2012). Where lakes form behind dams of moraine and ice, volumes of stored water can be as high as $10^{8} \mathrm{~m}^{3}$, in some cases posing considerable risk of glacier lake outburst floods (GLOFs) (Yamada, 1998; Richardson and Reynolds, 2000).

Several studies have shown that the development and enlargement of englacial conduits play an important role in the evolution of debris-covered glaciers during periods of negative mass balance (e.g. Clayton, 1964; Kirkbride, 1993; Krüger, 1994; Benn et al., 2001, 2009, 2012; Gulley and Benn, 2007; Thompson et al., 2016). The collapse of conduit roofs can expose areas of bare ice at the glacier surface, locally increasing ablation rates. Additionally, areas of subsidence associated with englacial conduits create closed hollows (dolines) that can evolve into supraglacial ponds, further increasing ice losses by calving. Conversely, supraglacial 
ponds can drain if a connection is made with the englacial drainage system, provided the pond is elevated above hydrological base level ("perched lakes" in the terminology of Benn et al., 2001, 2012). Drainage of relatively warm water through the glacier leads to conduit enlargement, which in turn increases the likelihood of roof collapse, surface subsidence, and ultimately new pond formation (Sakai et al., 2000; Miles et al., 2015). Because ablation rates around supraglacial pond margins are typically 1 or 2 orders of magnitude higher than those under continuous surface debris, ponds contribute disproportionately to overall rates of glacier ablation (Sakai et al., 1998, 2000, 2009; Thompson et al., 2016). By controlling the location and frequency of surface subsidence and pond drainage events, englacial conduits strongly influence overall ablation rates and the volume of water that can be stored in and on the glacier (Benn et al., 2012).

Speleological investigations in debris-covered glaciers in the Khumbu Himal have demonstrated that englacial conduits can form by three processes: (1) "cut and closure", or the incision of supraglacial stream beds followed by roof closure; (2) hydrologically assisted crevasse propagation, or hydrofracturing, which may route water to glacier beds; and (3) exploitation of secondary permeability in the ice (Gulley et al., 2009a, b; Benn et al., 2012). The relative importance of these processes in the development of glacial drainage systems, however, has not been investigated in detail. Furthermore, there are no data on the large-scale structure of englacial and subglacial glacial drainage systems in the Himalaya or on how they evolve during periods of negative mass balance. In this paper, we investigate the origin, configuration and evolution of the drainage system of Ngozumpa Glacier, using three complementary methods. First, speleological surveys of englacial conduits are used to provide a detailed understanding of their formation and evolution. Second, historical satellite imagery and high-resolution digital elevation models (DEMs) are used to identify past and present drainage pathways, glacier-wide patterns of surface water storage and release, and regions of subsidence. Finally, feature tracking on TerraSAR-X imagery is used to detect regions of the glacier subject to seasonal velocity fluctuations, as a proxy for variations in subglacial water storage. Taken together, these methods provide the first synoptic view of the drainage system of a large Himalayan debris-covered glacier and its influence on glacier response to recent warming.

\section{Study area and methods}

Ngozumpa Glacier is located in the upper Kosi River catchment, Khumbu Himal, Nepal (Fig. 1). It has three confluent branches: a western (W) branch flowing from the flanks of Cho Oyu (8188 m); a north-eastern (NE) branch originating below Gyachung Kang (7952 m); and an eastern (E) branch (Gaunara Glacier) nourished below a cirque of $6000 \mathrm{~m}$ peaks.

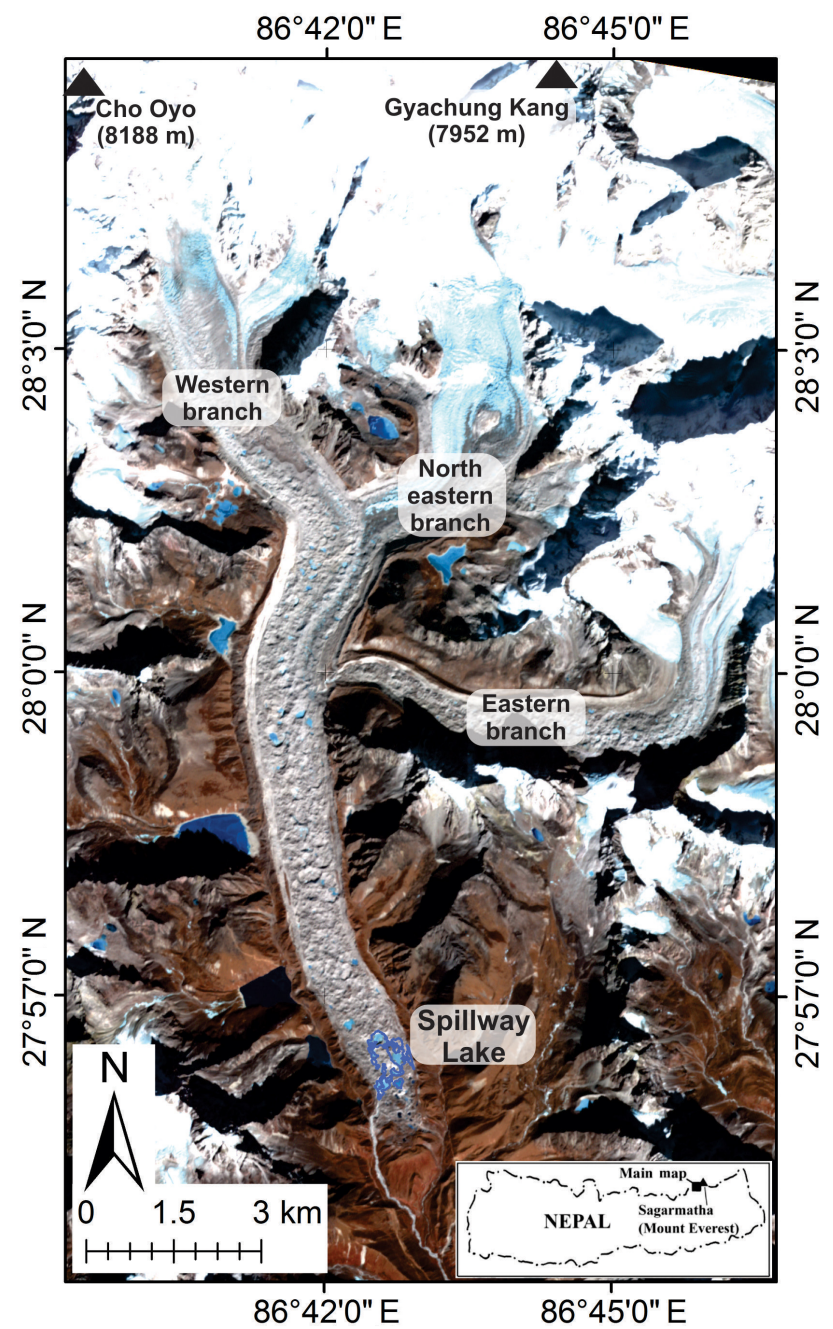

Figure 1. Ngozumpa Glacier, showing the location of the three branches and Spillway Lake. Image: orthorectified GeoEye-1 from December 2012.

The NE and E branches are no longer dynamically connected to the main trunk, which is fed solely by the $\mathrm{W}$ branch (Thompson et al., 2016). The equilibrium line altitude (ELA) is not well known. Google Earth images from 3 November 2009 (after the end of the ablation season) and 9 June 2010 (at the beginning of the monsoon accumulation season) show bare ice up to $\sim 5700 \mathrm{~m}$ above sea level (a.s.l.) on all three branches, and this value is adopted as an approximate value of the ELA.

The lower ablation zone of the glacier is effectively stagnant, with little or no detectable motion on most of the E branch, or on the main trunk for $\sim 6.5 \mathrm{~km}$ upglacier of the terminus (Bolch et al., 2008b; Quincey et al., 2009; Thompson et al., 2016). The lowermost $15 \mathrm{~km}$ of the glacier (below $\sim 5250$ ma.s.1.) is almost completely mantled with supraglacial debris. The debris cover thickens downglacier, reaching $1.80 \pm 1.21 \mathrm{~m}$ near the terminus (Nicholson, 2004; 


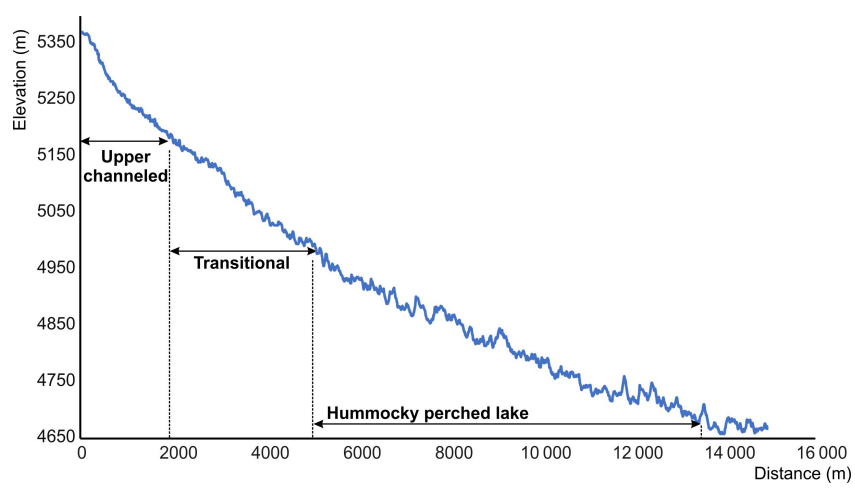

Figure 2. Longitudinal surface profile of the $\mathrm{W}$ branch and main trunk of Ngozumpa Glacier, showing downglacier changes in gradient and relative relief (see Fig. 3a for location). "Upper channeled", "transitional", and "hummocky perched lake" refer to the drainage zones described in Sects. 4.2 and 4.3.

Nicholson and Benn, 2012). In common with other large debris-covered glaciers in the region, Ngozumpa Glacier has undergone significant surface lowering in recent decades, and the glacier surface now lies $>100 \mathrm{~m}$ below the crest lines of the late Holocene lateral moraines (Bolch et al., 2008a, 2011).

The lower tongue of the glacier has a concave surface profile, with the overall gradient declining from 5.8 to $2.4^{\circ}$ between 5300 and $4650 \mathrm{~m}$ (Fig. 2). The ice surface also becomes increasingly irregular downglacier, and below $5000 \mathrm{~m}$ it forms numerous closed basins separated by mounds, ridges, and plateaux with a relative relief of 50$60 \mathrm{~m}$ (Figs. 2 and 3). Most basins contain supraglacial ponds, which typically persist for a few years before draining (Benn et al., 2001; 2009, 2012; Gulley and Benn, 2007). Near the terminus of Ngozumpa Glacier, a system of lakes is ponded behind the terminal moraine (informally named Spillway Lake; Fig. 1). This lake system increased in area by around $10 \%$ per year from the early 1990 s until 2009 , but between 2009 and 2015 it experienced a reduction of area and volume as a result of lake level lowering and redistribution of sediment (Thompson et al., 2012, 2016; Mertes et al., 2016). This hiatus is likely to be temporary, and continued growth of the lake is expected in the coming years, as has been the case with other "base-level lakes" in the region (Sakai et al., 2009).

We surveyed $2.3 \mathrm{~km}$ of englacial passages in Ngozumpa Glacier, using standard speleological techniques modified for glacier caves (Gulley and Benn, 2007). Conduit entrances were identified during systematic traverses of the glacier surfaces. Within each conduit, networks of survey lines were established by measuring the distance, azimuth, and inclination between successive marked stations using a Leica DISTO laser rangefinder and a Brunton SightMaster compass and inclinometer. Scaled drawings of passages in plan, profile, and cross section were then rendered in situ and include obser-
Table 1. Satellite imagery used in the paper.

\begin{tabular}{llrrr}
\hline Sensor & $\begin{array}{l}\text { Product } \\
\text { type }\end{array}$ & $\begin{array}{r}\text { Resolution } \\
(\mathrm{m})\end{array}$ & $\begin{array}{r}\text { Acquisition } \\
\text { date }\end{array}$ & $\begin{array}{r}\text { Cloud } \\
\text { cover } \\
(\%)\end{array}$ \\
\hline Corona & KH-4 & 3 & 4 Mar 1965 & - \\
Landsat 5 TM & Level T1 & 30 & 5 Mar 2009 & 17 \\
Landsat 5 TM & Level T1 & 30 & 8 May 2009 & 16 \\
Landsat 5 TM & Level T1 & 30 & 9 Jun 2009 & 28 \\
Landsat 5 TM & Level T1 & 30 & 16 Aug 2009 & 18 \\
GeoEye-1 & GeoStereo & Pan 0.46 & 9 Jun 2010 & 3 \\
& Pan/MSI & MSI 1.84 & & \\
GeoEye-1 & GeoStereo & Pan 0.46 & 23 Dec 2012 & 0 \\
& Pan/MSI & MSI 1.84 & & \\
WorldView-3 & GeoStereo & Pan 0.46 & 5 Jan 2015 & 0 \\
& Pan/MSI & MSI 1.84 & & \\
\hline
\end{tabular}

vations of glaciostructural and stratigraphic features exposed in passage walls, thereby allowing the origin and evolution of conduits to be reconstructed in detail. In this paper, we focus on five conduits, which exemplify different stages of conduit formation, abandonment, and reactivation. Three of the conduits have been previously described by Gulley and Benn (2007), but in this paper we revise our interpretation of their origin in some important respects. Some of the conduits drained water from or fed water into supraglacial ponds, and in some cases it was possible to relate phases of conduit development to specific pond filling or drainage events, identified in satellite images.

A range of optical imagery was used to map indicators of the large-scale structure of the drainage system (Table 1). The location of supraglacial channels and ephemeral supraglacial ponds was mapped using declassified Corona KH-4 (1965), Landsat 5 Thematic Mapper (TM, 2009), GeoEye-1 (9 June 2010 and 23 December 2012), and WorldView-3 (5 January 2015) imagery. The Corona and Landsat imagery was not co-registered or orthorectified beyond the standard terrain correction of the product and was used to identify the presence/absence of larger ponds or channels, not to quantify rates of change.

GeoEye-1 imagery from June 2010 and December 2012 and WorldView-3 imagery from January 2015 were acquired for a region covering $17.4 \mathrm{~km}^{2}$ of the ablation area of the glacier. Three stereoscopic DEMs of $1 \mathrm{~m}$ resolution were constructed from the stereo multispectral imagery (MSI) using the PCI Geomatica software package and used to determine spatial patterns of elevation change. The construction and correction of the DEMs is discussed in detail in Thompson et al. (2016).

The 2010 DEM was used to define the extent of individual surface drainage basins on the glacier surface. This was achieved by identifying surface elevation contours that entirely surround other contours of a lesser height. Each supraglacial catchment was then defined by the crest lines of ridges that separate the closed basins. Initially, we used $2 \mathrm{~m}$ 

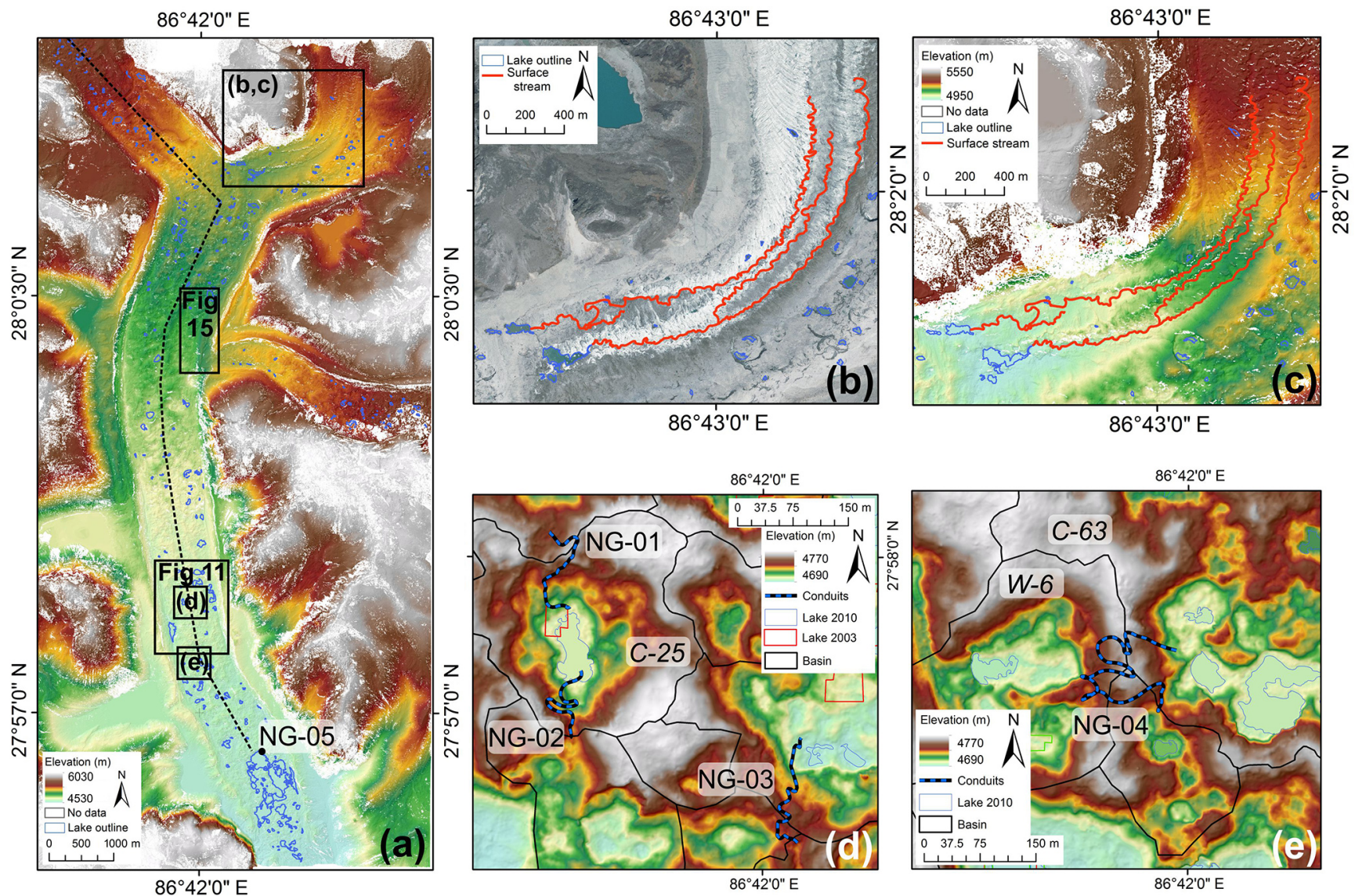

Figure 3. Examples of surface topography, supraglacial meltwater channels, and englacial conduit locations on Ngozumpa Glacier: (a) DEM of the lower ablation zone of the glacier, based on GeoEye-1 stereo imagery from June 2010, showing location of enlarged panels and englacial conduit NG-05; (b) supraglacial channels shown on the 2010 imagery; (c) the same area shown on the 2010 DEM; (d) hummocky debris-covered ice, showing the boundaries of closed surface basins and locations of englacial conduits NG-01 to NG-03 (considerable basin expansion occurred in the four ablation seasons between the conduit surveys (December 2005) and the date of the DEM (June 2010)); and (e) hummocky debris-covered ice and location of englacial conduit NG-04 (surveyed November 2009, 7 months before the date of the DEM). The dashed line in panel (a) shows the location of the long profile in Fig. 2.

contours, but these produced a large number of very small "basins", due to the high roughness of the bouldery glacier surface. Subsequently, we used $5 \mathrm{~m}$ contours that yielded a set of closed basins that closely matched the location of ephemeral supraglacial ponds on the glacier surface. The extent of many basins changed between 2010 and 2015 due to ice-cliff backwasting, although all basins persisted through the period covered by the DEMs. It was not possible to delineate basins on the historical Corona or Landsat imagery because our methods depend on the availability of DEMs and cannot be applied to mono images.

Glacier surface velocities were derived using feature tracking between synthetic aperture radar (SAR) images acquired by the TerraSAR-X satellite on 19 September 2014, 18 and 29 January 2015, and 5 January 2016. Feature tracking was done using the method of Luckman et al. (2007), which searches for a maximum correlation between evenly spaced subsets (patches) of each image, giving the displacement of glacier surface features which are converted to speed using time delay between images. Image patches were $\sim 400 \mathrm{~m} \times$ $400 \mathrm{~m}$ in size and sampled every $40 \mathrm{~m}$, producing a spatial resolution of between 40 and $400 \mathrm{~m}$ depending on feature density. Based on feature matching precise to one pixel $(2 \mathrm{~m})$, precision of the measured velocities is $0.006 \mathrm{~m} \mathrm{day}^{-1}$ over the annual (341-day) period and $0.018 \mathrm{~m} \mathrm{day}^{-1}$ over the winter (111-day) period. These values are used to define the threshold for detectable motion on the lower glacier.

\section{Mechanisms of englacial conduit formation}

To provide an overview of processes of englacial conduit formation on the glacier, we describe two sites in detail (NG-04 and NG-05) and then briefly describe and reinterpret three previously published sites (NG-01, NG-02, and NG-03; Gulley and Benn, 2007). 


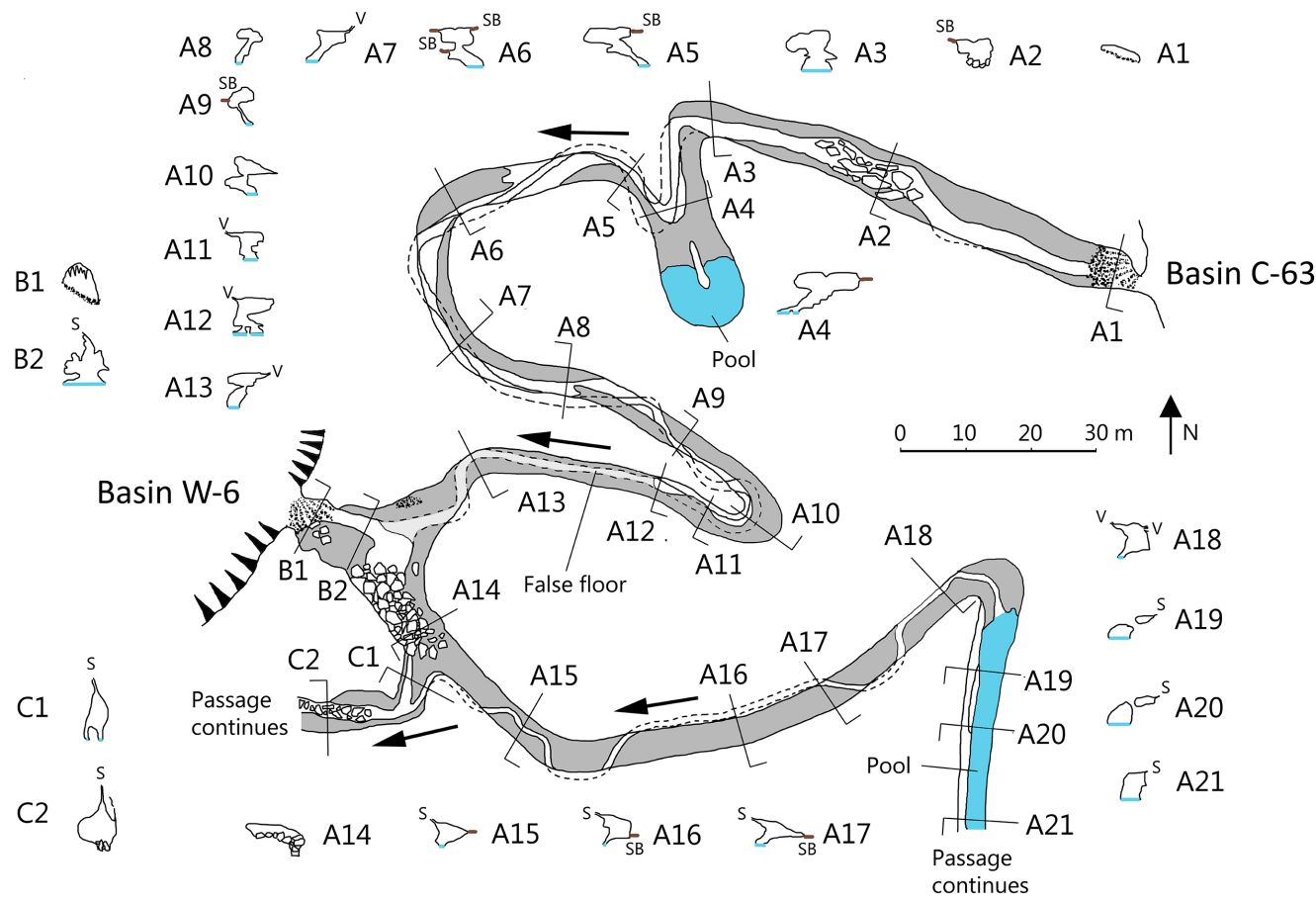

Figure 4. Plan and passage cross sections of englacial conduit NG-04. SB: sediment band; S: suture; V: voids. Dark-grey-filled and whitefilled areas within the cave plan indicate the floors of the upper and lower levels, respectively. Pale grey and dashed lines are used where the lower level is occluded by higher false floors. Standing water on the cave floor is shown in blue. For location, see Fig. 3e.

\subsection{NG-04}

\subsubsection{Description}

Conduit NG-04 $\left(27^{\circ} 57^{\prime} 24^{\prime \prime} \mathrm{N}, 86^{\circ} 41^{\prime} 55^{\prime \prime} \mathrm{E} ; 4805\right.$ m a.s.l.) was surveyed in November 2009 and consisted of a main passage (A) and two shorter side passages (B and C) leading off to the west (Fig. 4). The main passage extended from a large hollow on the glacier surface (basin C-63 in Figs. 3e and 10a) for a distance of at least $473 \mathrm{~m}$, where the survey was discontinued due to deep standing water on the cave floor. Side passage $\mathrm{B}$ also connected with a basin on the glacier surface (basin W-6, Figs. 3e and 10b). Side passage $\mathrm{C}$ was at least $25 \mathrm{~m}$ long but was not surveyed beyond this distance due to the evident instability of the highly fractured walls.

The main passage consisted of an upper level with a flat or gently inclined floor and a lower narrow incised canyon. The passage was highly sinuous, with a sinuosity in the surveyed reach of 5.52. Near A4 (Fig. 4), there was a tight cutoff meander loop off the main passage (Fig. 5a). The base of the abandoned loop had a flat floor and lacked the incised lower level that was present elsewhere in the system. The upper floor level could also be traced along the walls of side passages $\mathrm{B}$ and $\mathrm{C}$, which we interpret as twin remnants of a second meander cut-off. The floor of the upper level sloped gently downward from A1 to A14, rose from there to between A18 and A19, and then descended once more. Sandy bedforms on the floor and scallops on the ice walls of this upper level indicate that water flow was from A1 towards A21.

Passage morphology on the upper level was very variable, including tubular, box-shaped, triangular, and irregular sections (Figs. 4 and 5b-d). Throughout most of the system, planar structures were visible in the ceiling or walls of the upper level, running parallel to the passage axis with variable inclination. The structures took the form of (1) "sutures" at the line of contact between opposing walls (S; Fig. 4; Fig. 5b, c), (2) intermittent narrow voids (V; Fig. 4, Fig. 5c), and (3) bands of sorted sand or gravel a few centimetres thick (SB; Fig. 4, Fig. 5d). Some of the voids increased in width inward, in some cases opening out into gaps tens of centimetres across. In some places, bands of sorted sediment could be traced laterally into open voids or sutures. At several points along the main passage, a pair of planar structures occurred on opposite walls of the passage. Side passage B had a narrow, meandering seam of dirty ice running along its ceiling, and in passage $\mathrm{C}$ the walls tapered upward to meet at a ceiling suture.

The floor of the incised lower level in both parts of the main passage sloped down towards side passages B and C (arrows, Fig. 4). A pair of incised channels was confluent at $\mathrm{C} 1$, whereas a single incised channel was present in passage $\mathrm{B}$, where its lower (western) end was blocked by an accumulation of ice and debris. 

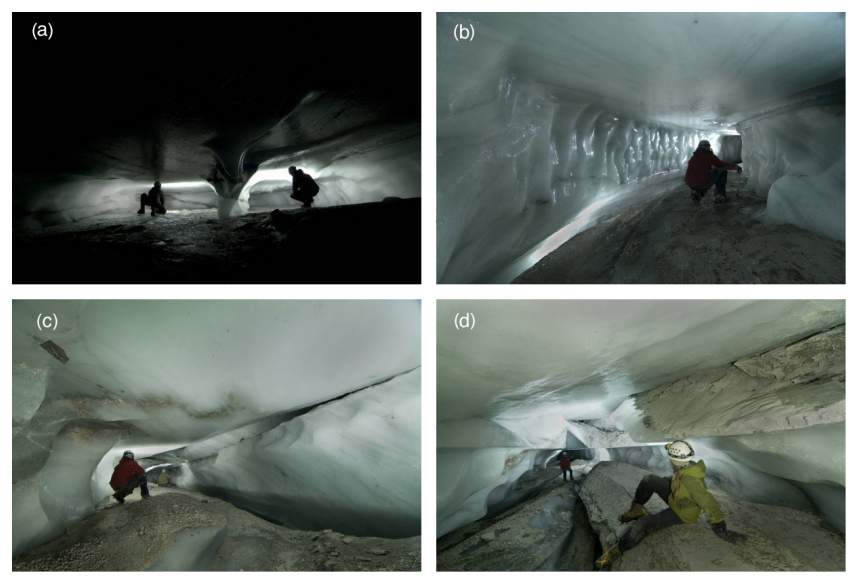

Figure 5. Passage morphology in NG-04. (a) Cut-off meander loop; note the inclined debris band on back wall behind the left-hand person. (b) The upper passage near A12, showing suture between the right-hand wall and the ceiling, and the incised lower passage on the left. (c) The upper passage near A7, with a void and suture between the right-hand wall and the ceiling. (d) The upper passage near A6, showing a band of bedded sand filling a sub-horizontal suture above the foreground person.

\subsubsection{Interpretation}

The partially debris-filled structures in the walls and ceiling of the upper level are closely similar to many examples of canyon sutures we have observed in cut-and-closure conduits in the Himalaya and Svalbard, marking the planes of closure where former passage walls have been brought together by ice creep and/or blocked by ice and debris (cf. Gulley et al., 2009a, b). Cut-and-closure conduits are typically highly sinuous and have variable cross-sectional morphologies, ranging from simple plugged canyons (incised channels with roofs of névé), to sutured canyons (partially or completely closed by ice creep), horizontal slots (formed by lateral channel migration followed by roof closure), and tubular passages (where passage re-enlargement has occurred under pipe-full (phreatic) conditions; Gulley et al., 2009b). The tubular morphology of the upper passage in NG-04 combined with the sutures, voids, and sediment bands in the walls and ceiling - indicates that the passage has been re-enlarged under pipe-full conditions following an episode of almost complete closure. For example, the sub-horizontal bands of sorted sand on both conduit walls between A15 and A18 (Fig. 5d) suggest complete suturing of a low, wide reach (horizontal slot) prior to formation of the surveyed passage.

The tubular and box-shaped cross profiles and undulating long profile of the upper passage are consistent with fluvial erosion under pipe-full or phreatic conditions (cf. Gulley et al., 2009b). This contrasts with the canyon-like form and consistent down-flow slope of channels incised under atmospheric (vadose) conditions, typical of simple cut-andclosure conduits. The dimensions of the upper passage (typ-

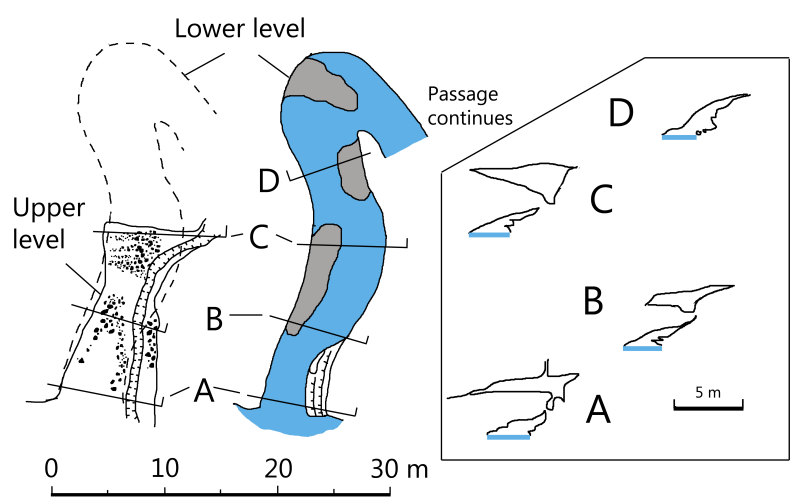

Figure 6. Plan and passage cross sections of conduit NG-05. The plan view of the upper level shows boulders and an incised channel on the conduit floor. For location see Fig. 3a.

ically $2 \mathrm{~m}$ high and $3 \mathrm{~m}$ wide) are consistent with high discharges. We conclude that the upper passage formed when water draining from a supraglacial pond in basin C-63 exploited the remnants of an abandoned cut-and-closure conduit (Fig. 3e).

Following formation of the upper passage, the lower level was incised under vadose (non-pipe-full) conditions when the system accessed a new local base level via side passages $\mathrm{B}$ and $\mathrm{C}$. We infer that this occurred when a cut-off meander loop between $\mathrm{B} 1$ and $\mathrm{C} 2$ was exposed by ice-cliff retreat in basin W-6. Water flow between A1 and B2 continued in the same direction as before, but between A14 and A21 flow was reversed and discharge much reduced.

Evolution of conduit NG-04 can be summarized as follows: (1) a cut-and-closure conduit was formed by incision of a supraglacial stream; (2) this conduit was abandoned and almost completely closed, presumably after it lost all or most of its source of recharge following downwasting of the overlying glacier surface; (3) the conduit remnants were exploited and enlarged by water draining from a supraglacial pond in basin C-63; and (4) surface ablation in basin W-6 broke into the conduit, creating a new base level and initiating floor incision. This remarkable cave illustrates how relict drainage systems can be reactivated when connected to new sources of recharge and demonstrates how patterns of drainage can change dramatically within a single system in response to changing surface topography.

\subsection{NG-05}

\subsubsection{Description}

In December 2009 a conduit portal was exposed in an ice cliff at the margin of Spillway Lake $\left(27^{\circ} 56^{\prime} 36^{\prime \prime} \mathrm{N}, 86^{\circ} 42^{\prime} 46^{\prime \prime} \mathrm{E}\right.$; 4670 ma.s.l.; Figs. 3a and 6). This portal was one of the two main efflux points that discharged water into the lake from upglacier (Thompson et al., 2016). Access to the conduit could be gained via the frozen lake surface (Fig. 7a), 
although the lake ice was broken up each morning by debris falling from the melting glacier surface above, severely limiting the time available for survey. Consequently, only a short section could be mapped (Fig. 6). The conduit had two main levels, separated by a narrow, partially ice-filled canyon. The floor of the lower part was at lake level, and that of the upper level was $4.8 \mathrm{~m}$ higher, close to the summer monsoon level of the lake, as indicated by shorelines exposed around the lake margins. Several notches on the passage walls recorded intermediate water levels. The ice cliff above the upper level was obscured by a mass of icicles, but observations inside the cave showed that the roof tapered up into a narrow debris band or suture.

\subsubsection{Interpretation}

Although short, this passage is important for understanding the drainage system of Ngozumpa Glacier. The debris band and suture in the roof indicate that, like NG-04, the passage formed by a process of channel incision and roof closure. Additionally, the passage is graded to the seasonally fluctuating surface of Spillway Lake. We therefore conclude that the main drainage on the eastern side of the glacier consists of a cut-and-closure conduit graded to the hydrologic base level of the glacier. For several kilometres upglacier of the portal, the debris-covered ice surface is highly irregular and broken into numerous closed basins, implying that the conduit evolved from a surface stream that predates significant downwasting of the glacier. The significance of these conclusions will be discussed later in the paper.

\subsection{NG-01, NG-02, and NG-03}

\subsubsection{Description}

NG-01, NG-02, and NG-03 (Fig. 3d) were mapped in December 2005 and described by Gulley and Benn (2007). NG-01 had carried water southward into a large basin on the glacier surface (basin C-25, Fig. 10a), whereas NG-02 drained water southward out of the basin. NG-01 $\left(27^{\circ} 57^{\prime} 58^{\prime \prime} \mathrm{N}, 86^{\circ} 41^{\prime} 50^{\prime \prime} \mathrm{E}\right)$ was a sinuous canyon passage with three main levels. Debris bands cropped out in the walls of the uppermost level throughout its length, either at the lateral margins of the passage or in the roof (Fig. 7b). The mid-level had a sub-horizontal floor, into which the canyon linking to the lower level had been incised (Fig. 7c). NG-02 $\left(27^{\circ} 57^{\prime} 55^{\prime \prime} \mathrm{N}, 86^{\circ} 41^{\prime} 51^{\prime \prime} \mathrm{E}\right)$ was a sinuous canyon passage on two levels, extending in a southwesterly direction from the basin. The upper level had a circular cross profile, and an incised canyon beneath formed the lower level. A suture and debris band were exposed along the entire length of the ceiling of the upper passage, mirroring the planform of the passage (Fig. 7d). The lower level was an asymmetric flatfloored passage with a series of sills along the margins. NG$03\left(27^{\circ} 57^{\prime} 52^{\prime \prime} \mathrm{N}, 86^{\circ} 42^{\prime} 02^{\prime \prime} \mathrm{E}\right)$ consisted of a single passage
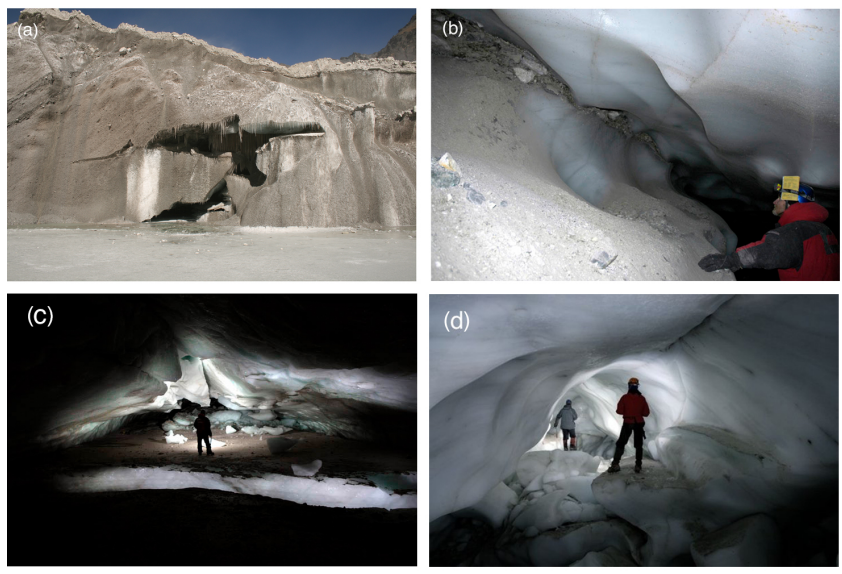

Figure 7. (a) The entrance of NG-05 on the NW margin of Spillway Lake; (b) NG-01: debris-filled canyon suture at the upper level of the cave; (c) NG-01: flat-floored mid-level of the cave (note canyon suture above and incised lower level crossing foreground from left to right); (d) NG-02: tubular upper passage with canyon suture in the roof.

graded to a supraglacial pond in basin E-19. Passage morphology varied between a low, wide semi-elliptical crosssection and a more complex form with an elliptical upper section separated by a narrow neck from a lower A-shaped section. At the top of the canyon, the ceiling narrowed to a narrow slot, terminating in a band of coarse, unfrozen sandy debris.

\subsubsection{Interpretation}

For much of their length, all three conduits follow the trend of debris bands in the walls or roof, leading Gulley and Benn (2007) to conclude that all were structurally controlled. The debris bands were originally interpreted as debris-filled crevasse traces that had been deformed during advection downglacier. When the original work was conducted, the cutand-closure model had not been developed, and we had yet to learn how to recognize the diverse forms such conduits can take, especially in the later stages of their development. It is now apparent that these conduits have all the hallmarks of cut-and-closure conduits. The continuity and sinuous planform of the debris bands are consistent with formation by the closure of incised canyons, rather than crevasse fills that had been deformed by ice flow. Crevasses in the upper part of the glacier ablation area tend to be short, discontinuous, and oriented transverse to flow, unlike the observed debris bands in the conduit roofs, and ice deformation is unlikely to be capable of generating the highly sinuous patterns observed within the conduit debris bands.

We therefore reinterpret NG-01-NG-03 as cut-and-closure conduits that have undergone cycles of incision, abandonment, partial closure, and later reactivation in response to fluctuating patterns of recharge on the glacier surface. The 

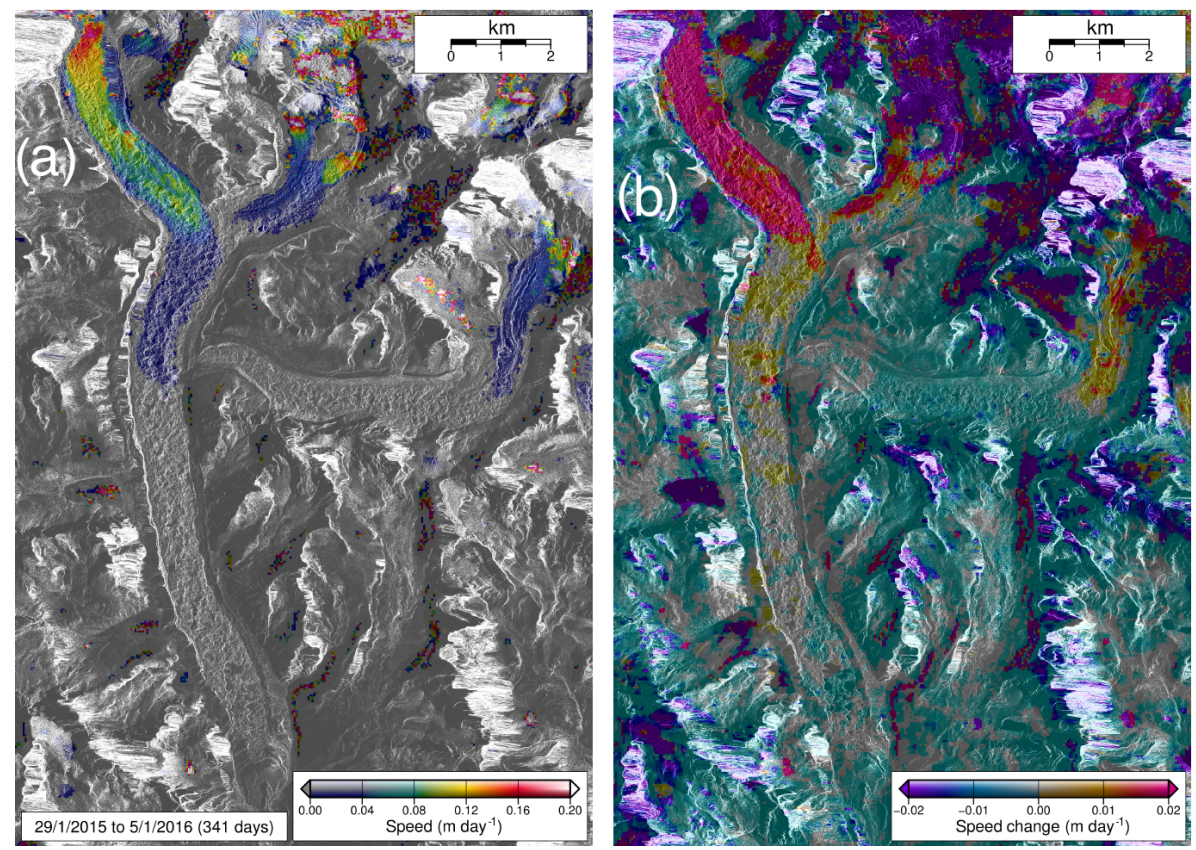

Figure 8. Surface velocities derived from TerraSAR-X data: (a) mean daily velocity for the "annual" period (29 January 2015 to 5 January 2016); (b) velocity difference between "annual" period (29 January 2015 to 5 January 2016) and "winter" period (19 September 2014 to 18 January 2015), indicating minimum summer speed-up of the glacier. No masks or filters were applied to the data.

circular and elliptical cross profiles observed in NG-02 and NG-03 are consistent with phases of phreatic passage enlargement, analogous to that in NG-04. Abandoned, incompletely closed conduits create hydraulically efficient flow paths, which can be readily exploited and enlarged when surface ablation brings them into contact with new sources of recharge.

\section{Drainage system structure}

In this section, we present evidence for the large-scale structure of the drainage system and patterns of water storage and release, using X-band radar and optical satellite imagery and high-resolution DEMs from 2010, 2012, and 2015.

\subsection{Subglacial drainage system}

\subsubsection{Observations}

Direct observation of the subglacial drainage system was not possible. Instead, we use seasonal fluctuations in glacier surface velocity to infer areas subject to variable subglacial water storage. Mean daily ice velocities of the glacier between 29 January 2015 and 5 January 2016 are shown in Fig. 8a. There is no detectable motion (i.e. greater than $\sim 0.01 \mathrm{~m} \mathrm{day}^{-1}$ ) on the main trunk within $\sim 6.5 \mathrm{~km}$ of the terminus or on the lowermost $6 \mathrm{~km}$ of the $\mathrm{E}$ branch. The W branch is the most active, with velocities of $\sim 0.16 \mathrm{~m} \mathrm{day}^{-1}$ $\left(\sim 60 \mathrm{myr}^{-1}\right)$ at $5300 \mathrm{ma}$ a.s.l., declining to near zero at
$4900 \mathrm{~m}$. The NE branch is slower, although velocities in its upper part could not be determined due to image "lay-over" in steep terrain. The active part of the NE branch does not extend as far down as the confluence with the $\mathrm{W}$ branch, and a strip of stagnant ice $\sim 100-200 \mathrm{~m}$ wide extends $\sim 3 \mathrm{~km}$ down the eastern side of the main trunk from the confluence zone. Thus, neither the E nor the NE branch is dynamically connected to the main trunk.

Evidence for seasonal velocity fluctuations is shown in Fig. 8b, which shows mean daily velocities between 29 January 2015 and 5 January 2016 (341 days) minus mean daily velocities from 19 September 2014 to 18 January 2015 (111 days). Meteorological data from the Pyramid Weather Station, at $5050 \mathrm{~m}$ a.s.l. and ca. $12 \mathrm{~km}$ east of Ngozumpa Glacier (available through the Ev-K2-CNR Stations at High Altitude for Research on the Environment (SHARE) project), indicate that air temperatures were consistently below freezing between 25 September 2014 and 28 May 2015, defining a minimum winter period for the upper ablation zone. The 111-day interval lies almost entirely within the winter period but is less than half of its total duration, so Fig. $8 \mathrm{~b}$ yields minimum values for a summer speed-up on the glacier. Most of the active parts of the glacier exhibit some speedup, although it is much more pronounced in some areas than others. On the $\mathrm{W}$ branch, the greatest speed-up (by $\sim 0.015 \mathrm{mday}^{-1}$ or $\sim 10 \%$ ) occurs above the confluence with the NE branch. Areas of lesser speed-up also occur on the main trunk below this point, although these are discontinuous and less than the margin of error and so are likely to 
be artefacts. Only the northern side of the NE branch is affected by a seasonal speed-up. This area coincides with the tongue of clean ice that descends through the icefall below Gyachung Kang (Fig. 1). Patchy areas of apparent speed-up and slow-down occur elsewhere on the NE branch but may be artefacts. A small speed-up also affects the active part of the E branch, above $5350 \mathrm{~m}$ a.s.1.

\subsubsection{Interpretation}

The seasonal variations in ice velocities in the upper ablation zone are too large to be explained by changes in ice creep rates, which would require fluctuations in driving stress that are inconsistent with the observed surface elevation changes on the glacier (Thompson et al., 2016). We interpret the velocity data as evidence for variations in basal motion (sliding and/or subglacial till deformation) in response to changing subglacial water storage. This interpretation is supported by the spatial distribution of areas affected by the seasonal speed-up, which coincide with, or occur downglacier of, heavily crevassed ice. Much of the upper ablation area of Ngozumpa Glacier consists of icefalls with surface gradients up to $30^{\circ}$, and fields of transverse crevasses occur across the entire width of the $\mathrm{W}$ branch down to an elevation of $5270 \mathrm{~m}$ (Fig. 9a). Below this zone, crevasses are largely absent, reflecting decreasing ice velocities and compressive flow (Fig. 9b, c, and d; cf. Fig. 8). Fields of transverse crevasses occur in the upper basin of the $\mathrm{E}$ branch, above $\sim 5400 \mathrm{~m}$. Crevasses allow meltwater to be routed rapidly to the bed, and the existence of multiple recharge points will encourage development of a distributed drainage system following the onset of the monsoon ablation season. The lack of a clear seasonal velocity response on the lowermost $10 \mathrm{~km}$ of the glacier suggests that subglacial water is transported along the main trunk in efficient conduits, possibly along the glacier margins (see Sect. 4.4).

\subsection{Supraglacial channels}

\subsubsection{Observations}

Supraglacial stream networks are visible below the crevassed zones on all three branches of the glacier. The most extensive network occurs on the tongue of clean ice on the NE branch, where a set of sub-parallel channels descends from $\sim 5180 \mathrm{~m}$ to the junction with the $\mathrm{W}$ branch at $\sim 4990 \mathrm{~m}$ (Fig. 3b, c; Fig. 14a). There are several discontinuous supraglacial channels on the $\mathrm{W}$ branch between $5220 \mathrm{~m}$ and $5120 \mathrm{~m}$ a.s.1., including one along the eastern margin of the glacier. Supraglacial channels occur on both flanks of the E branch below $\sim 5100 \mathrm{~m}$ a.s.1. The channels converge at the junction with the main trunk, and after flowing over the glacier surface for several hundred metres the combined stream sinks in a large hollow in basin E-11. Patterns of water storage and release in this hollow are discussed in Sect. 4.4.

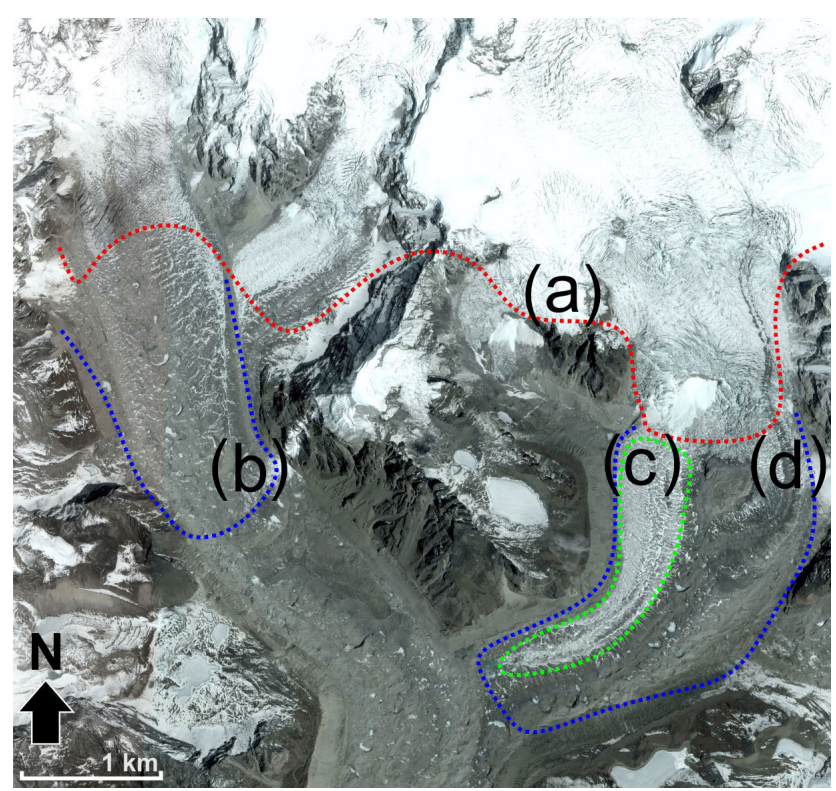

Figure 9. Distribution of crevasses on the $\mathrm{W}$ and NE branches of Ngozumpa Glacier. (a) Lower boundary of crevasse fields; $(\mathbf{b}, \mathbf{c}, \mathbf{d})$ areas where supraglacial channels occur on debris-covered and clean (c) ice. Image source: Google Earth.

\subsubsection{Interpretation}

Perennial supraglacial channels can only persist if the annual amount of channel incision exceeds the amount of surface lowering of the adjacent ice (Gulley et al., 2009b). The rate at which ice-floored channels incise is controlled by viscous heat dissipation associated with turbulent flow and increases with discharge and surface slope (Fountain and Walder, 1998; Jarosch and Gudmundsson, 2012). Because supraglacial stream discharge is a function of surface melt rate and melt area, significant channel incision requires large catchment areas. Therefore, incised surface channels tend to occur only where potential catchments are not fragmented by crevasses or hummocky surface topography (Fig. 3). At present, these conditions are met in relatively limited areas of Ngozumpa Glacier, below crevassed areas and above hummocky debris-covered areas.

\subsection{Hummocky debris-covered areas and perched ponds}

\subsubsection{Observations}

Most of the lower ablation zone of the glacier (below $\sim 5000 \mathrm{~m}$ ) consists of hummocky debris-covered topography, where the glacier surface is broken up into distinct closed depressions, each of which forms a separate surface drainage basin (Fig. 3d, e). Not including the Spillway Lake basin that drains externally, we defined 111 surface basins in this zone in 2010 (Fig. 10). Some surface basins also occur 

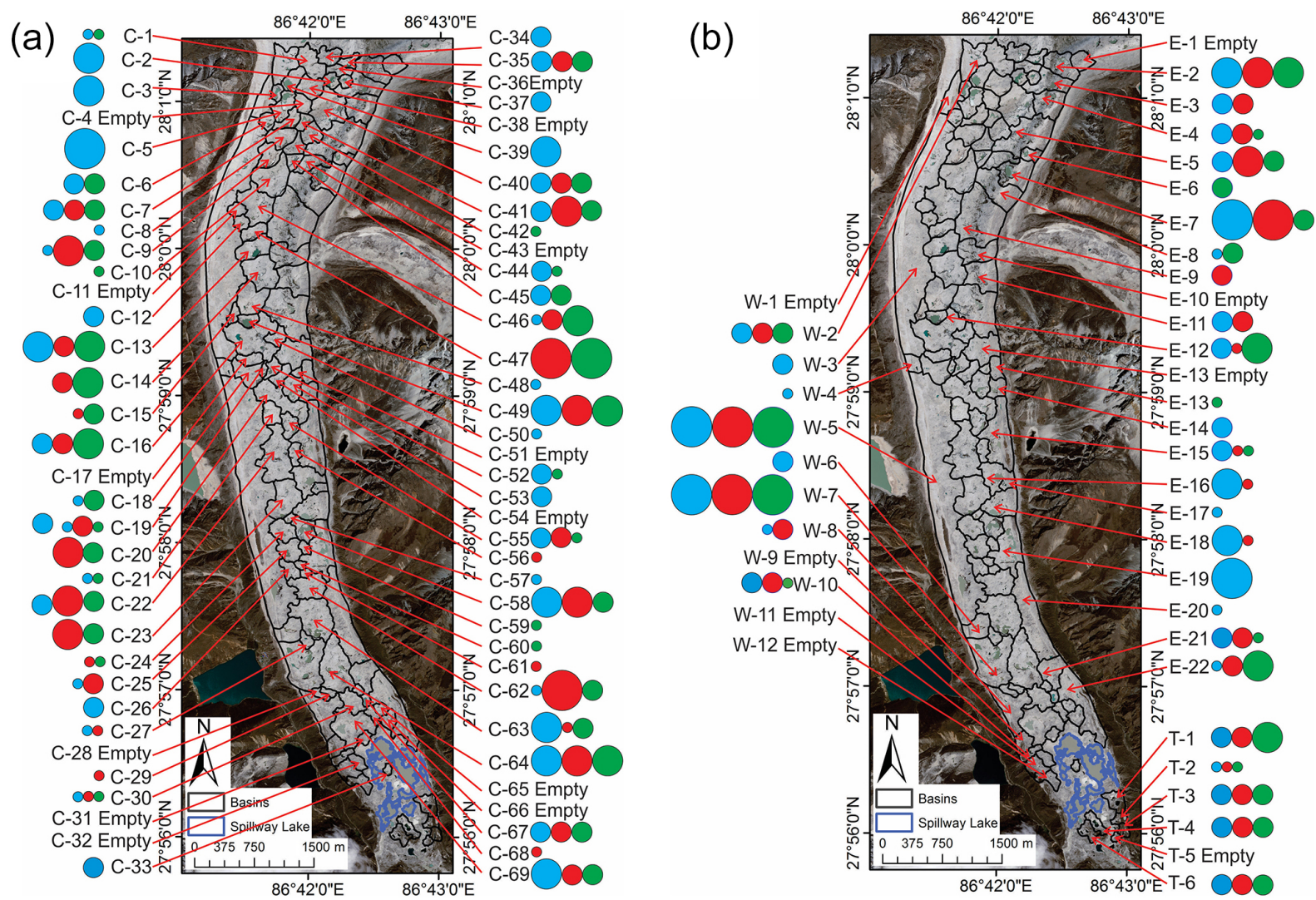

Figure 10. Surface drainage basins and lake area changes: (a) the central part of the glacier and (b) the lateral margins and terminal zone. Lake areas are shown for 2010 (blue), 2012 (red), and 2015 (green) in four categories: $<1000 \mathrm{~m}^{2}$ (small circles), 1000-5000 $\mathrm{m}^{2}$ (medium circles), 5000-10000 $\mathrm{m}^{2}$ (large circles), and $>10000 \mathrm{~m}^{2}$ (largest circles). Missing coloured circles indicate empty basins in that year.

between 5000 and $5100 \mathrm{~m}$ on the $\mathrm{W}$ Branch, but these are typically small, shallow, and ill-defined (Fig. 3). This part of the glacier is steeper $\left(3.4^{\circ}\right)$ and has lower relative relief $(\sim 10 \mathrm{~m})$ than the lower glacier, and it appears to be a transitional zone between the channelized upper ablation area and the hummocky debris-covered zone (Fig. 2). Surface basins along the east and west margins of the glacier form a series of depressions within almost continuous lateral troughs, and are considered in Sect. 4.4. Here, we focus on the basins in the central part of the glacier (C1-C69, Fig. 10a) and the terminal zone (T1-T6, Fig. 10b).

Of the 70 basins in the central part of the glacier, $56(80 \%)$ contained ponds in at least 1 of the 3 years covered by the GeoEye and WorldView imagery. Fifteen of the 42 ponds present in 2010 (36\%) had disappeared by 2012 or 2015 , whereas 14 basins that were empty in 2010 contained ponds in 1 or more of the later years. Almost all of the remainder underwent partial drainage and/or refilling. In contrast, the five ponds in the terminal zone of the glacier (below Spillway Lake) clearly exhibited stability. Four showed no significant change in area between 2010 and 2015, while the other showed an increase in area.

\subsubsection{Interpretation}

Observations on and below the glacier surface show that drainage of perched ponds occurs when part of the floor is brought into contact with permeable structures in the ice (Benn et al., 2001; Gulley and Benn, 2007). The characteristics of NG-01-NG-05 (which all occur within the hummocky debris-covered zone) show that relict cut-and-closure conduits are the dominant cause of secondary permeability in the glacier, providing pre-existing lines of weakness along which perched ponds can drain.

The spatial extent and high temporal frequency of perched pond drainage events on the glacier (Fig. 10a) imply a high density of active or relict conduits within the ice. A rough estimate can be obtained by dividing the number of complete and partial drainage events (35) by the total area of basins in the central part of the glacier $\left(4.62 \mathrm{~km}^{2}\right)$, yielding $\sim 7.6$ relict conduit reaches per square kilometre. This is a minimum estimate, because additional conduit remnants could occur below and beyond the margins of observed ponds. Conversely, the number of pond filling events ( 23 over the $5 \mathrm{ab}-$ lation seasons spanned by the imagery) shows that drainage routes commonly become blocked. Conduit blockage pro- 

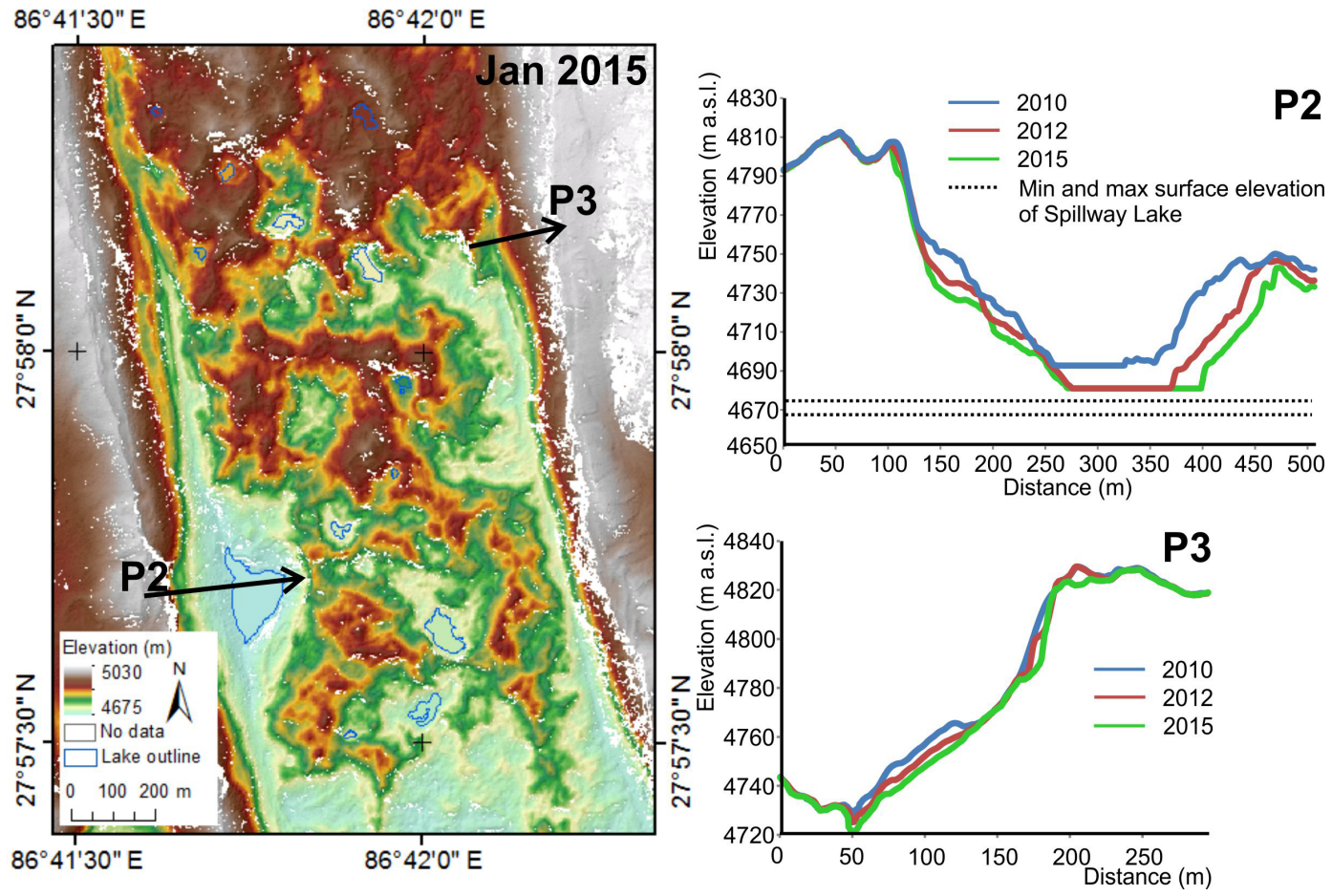

Figure 11. Extract from the 2015 DEM and selected cross profiles in 2010, 2012, and 2015, showing lateral troughs, subsidence of trough floors, and erosion of moraine slopes.

cesses have been described by Gulley et al. (2009b) and include accumulation of icicles or floor-ice at the end of the melt season and creep closure of opposing conduit walls. The interplay between drainage events and conduit blockage maintains a dynamic population of supraglacial ponds, which contribute significantly to ablation of the glacier, through absorption of solar radiation and ice melt, and calving (Thompson et al., 2016).

The stability of ponds in the terminal zone probably reflects a combination of factors. These ponds are flanked by stable slopes of thick debris, which inhibit pond growth by melt or calving. Furthermore, the ponds are located at or close to the hydrologic base level of the glacier, determined by the terminal moraine that encircles the glacier terminus, inhibiting drainage via relict conduits.

\subsection{Sub-marginal drainage}

\subsubsection{Observations}

Elevation differences between successive DEMs indicate linear zones of enhanced surface lowering along both margins of Ngozumpa Glacier, forming troughs along the base of the bounding lateral moraines (Thompson et al., 2016; Fig. 11). The inner moraine slopes consist of unvegetated, unconsolidated till and undergo active erosion by a range of processes, including rockfall, debris flow, and rotational landslipping (Benn et al., 2012; Thompson et al., 2016). Although debris eroded from the moraine slopes is transferred downslope into the troughs, the troughs underwent surface lowering of 6-9 m from 2010 to 2015 , with a total annual volume loss in the moraine-trough systems of $\sim 0.4 \times 10^{6} \mathrm{~m}^{3} \mathrm{yr}^{-1}$ (Thompson et al., 2016). This implies that a large volume of ice, debris, or both is evacuated annually from below the lateral margins of the glacier.

The lateral troughs form a series of closed basins, 12 on the west side and 22 on the east (Fig. 10b). Eight of the basins in the west trough and 17 of those in the east contained a pond in 2010, 4 (W) and 7 (E) of which had completely drained by 2012 or 2015 . Four new ponds appeared in the eastern trough in 2012 or 2015, and 1 (W) and 7 (E) underwent partial drainage and/or refilling. Three basins on the western side and one on the eastern side showed no fluctuations in pond area.

Benn et al. (2001) provided detailed descriptions of pond filling and drainage cycles in basins W-7 and W-5 (lakes 7092 and 7093, respectively, in their terminology). In October 1998, basin W-7 contained three shallow ponds, but by October 1999 the basin was occupied by a single large pond, and water level had risen by $\sim 9 \mathrm{~m}$. Pond area had increased from 17890 to $52550 \mathrm{~m}^{2}$, with $36 \%$ of the increase attributable to backwasting and calving of the surrounding ice cliffs. By September 2000, the pond had almost completely drained and only shallow ponds remained. Pond drainage occurred via an englacial conduit, which had 

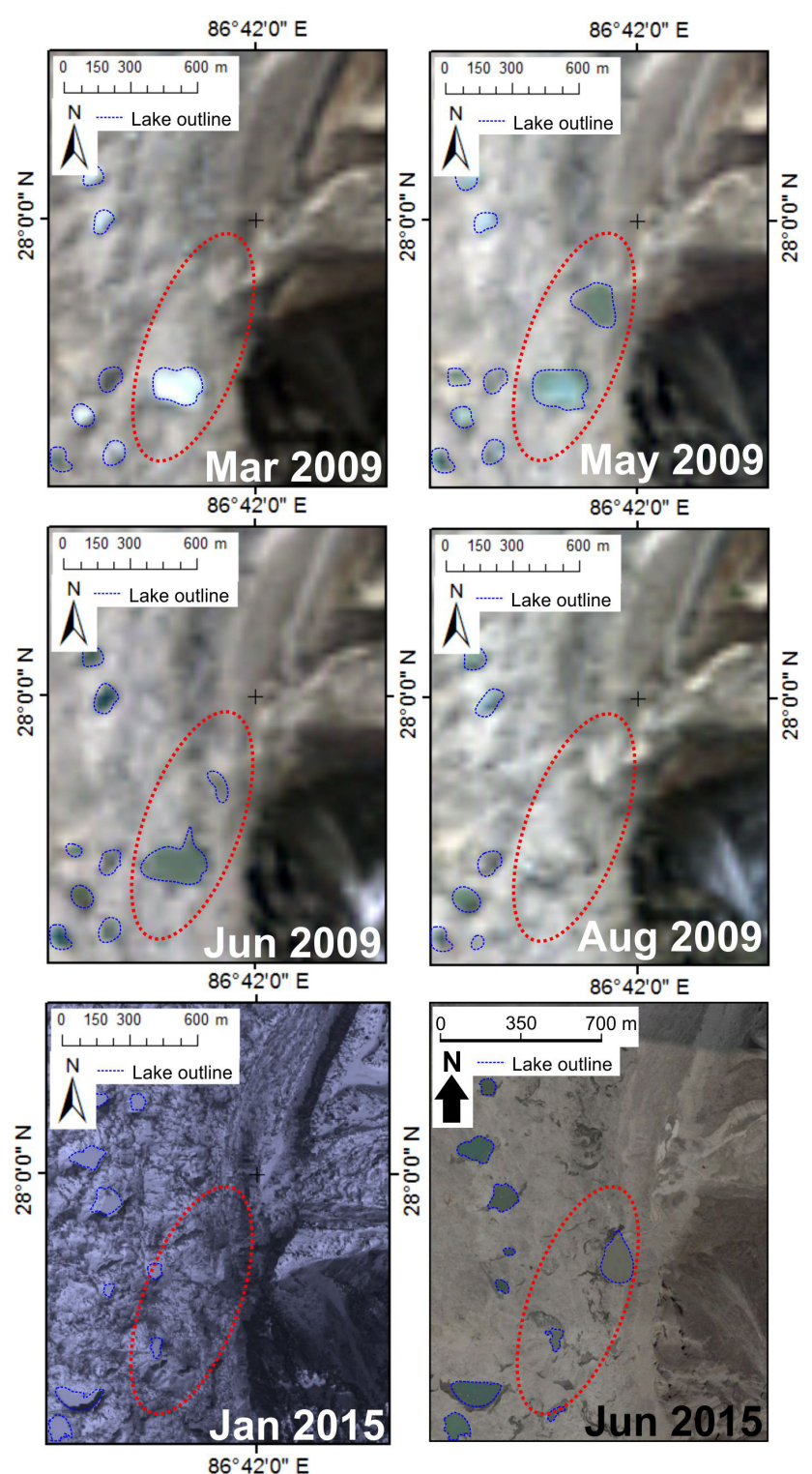

Figure 12. Changing pond extent in basin E-11, showing evidence of filling and drainage cycles. Pond outlines highlighted in blue.

been exposed by retreat of the pond margin. A pond in basin W-5 also underwent fluctuations in area and depth between 1998 and 2000 but did not completely drain during that time. Horodyskyj (2015) used time-lapse photography and a pressure transducer to document rapid pond-level fluctuations in basin W-5, including rises and falls of several metres within hours.

Short-term cycles of pond drainage and filling can also be demonstrated in other basins within the lateral trough systems using optical satellite imagery. Figure 12 shows a series of images of the east side of the glacier close to the junction with the E branch, where a supraglacial stream (Sect. 4.2) flows into a closed depression in basin E-11 (Fig. 10b). A pond occupying the basin expanded in area between March and May 2009 but drained between June and August. In 2015 there is little evidence of the pond in January, but a large pond is present in June.

\subsubsection{Interpretation}

Widespread, rapid subsidence along both margins of the glacier can be explained by enlargement and episodic collapse of sub-marginal conduits (Thompson et al., 2016). Potential internal ablation rates were calculated from energy losses associated with runoff and supraglacial pond drainage, and the resulting value of 0.12 to $0.13 \times 10^{6} \mathrm{~m}^{3} \mathrm{yr}^{-1}$ is around $30 \%$ of the measured volume losses in the moraine-trough systems on the stagnant part of the glacier, the difference being at least partly attributable to sediment evacuation by meltwater.

The sub-marginal conduits are perennial features of the glacier drainage system and discharge water into Spillway Lake during the winter months. Winter discharge may partly reflect slow release of water from supraglacial and englacial storage, but it may also partly consist of subglacial water from the upper ablation zone (see Sect. 4.1). This hints at the possibility that the sub-marginal channels function as the downglacier continuations of the subglacial drainage system, in addition to carrying water transferred more directly from the glacier surface.

Much of the lower ablation zone appears to be bypassed by the sub-marginal conduits, as evidenced by widespread water storage in supraglacial ponds (Sect. 4.3). As noted above, water is intermittently discharged from ponds in the central part of the glacier into the lateral troughs via englacial conduits. Cycles of pond drainage and filling in lateral basins indicate intermittent connections between surface catchments and the sub-marginal meltwater channels (Fig. 10b). In some cases, drainage events can be directly attributed to exploitation of englacial conduits (Benn et al., 2001). The hourly changes in pond level recorded by Horodyskyj (2015) cannot be explained by conduit opening and blockage, and they more likely reflect short-term fluctuations in recharge from surface melt and water release from storage.

\subsection{Spillway Lake}

\section{Observations}

In 2010, the area of the Spillway Lake surface catchment was $0.8 \mathrm{~km}^{2}$, of which $0.27 \mathrm{~km}^{2}$ was occupied by the lake system. All of the water leaving the glacier passes through Spillway Lake, entering via portals or upwellings at or close to lake level and leaving via a gap in the western lateral moraine $\sim 1 \mathrm{~km}$ from the glacier terminus (1; Fig. 13). (It is possible that water also exits the glacier via groundwater flow, although no springs have been observed in the frontal moraine ramp.) In 2009, conduit NG-05 (Fig. 6; Sect. 3.2) entered the 


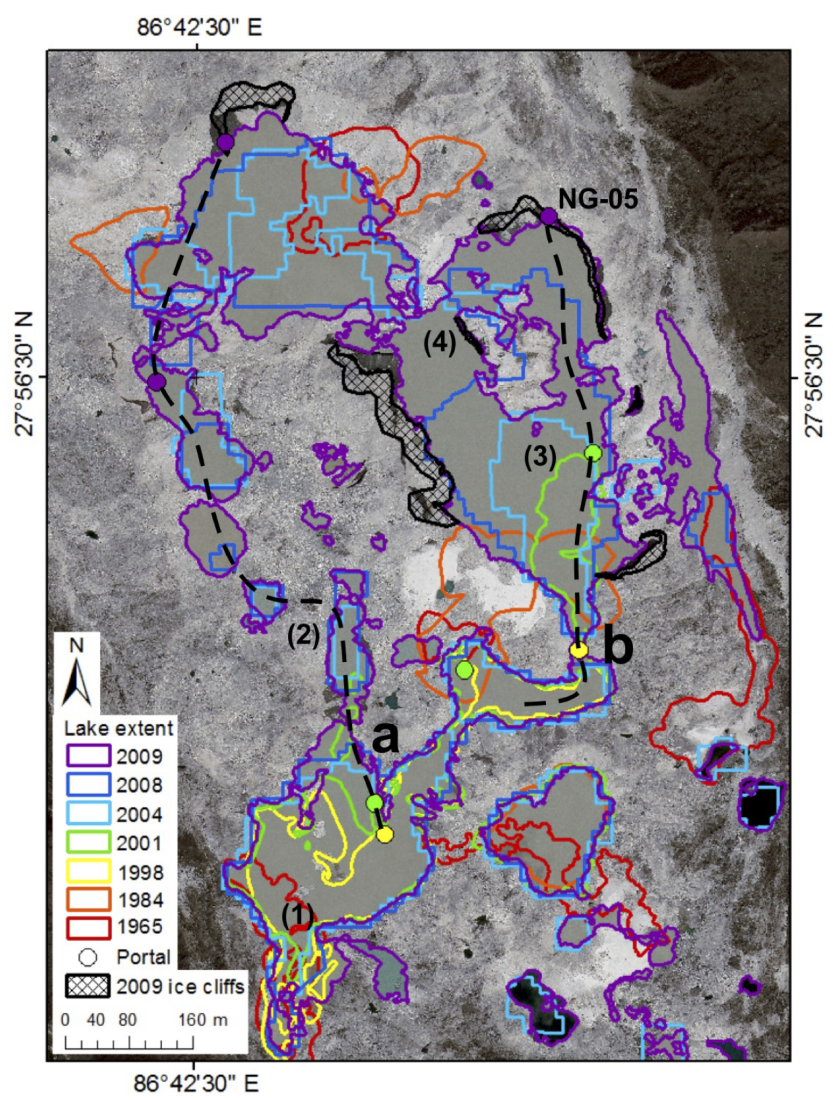

Figure 13. Spillway Lake, 1965-2009, showing the position of meltwater portals and upwellings and the inferred location of former englacial conduits (dashed lines). Background image: GeoEye1 from June 2010. See text for explanation of lake evolution.

NE corner of the Spillway Lake and is interpreted as the distal part of the eastern sub-marginal conduit. A second conduit portal visible at the NW lake margin in the same year is interpreted as the efflux point of the western sub-marginal stream. The evolution of the Spillway Lake system and its implications for drainage system structure in this part of the glacier are examined in Sect. 5.4 below.

\subsection{Summary}

The evidence presented above demonstrates that the drainage system of Ngozumpa Glacier comprises six linked elements: (1) a seasonal subglacial drainage system below the upper ablation zone; (2) supraglacial channels, allowing efficient meltwater transport across parts of the upper ablation zone; (3) sub-marginal channels, allowing long-distance transport of meltwater; (4) perched ponds, which intermittently store meltwater prior to evacuation via the englacial drainage system; (5) englacial cut-and-closure conduits, which may undergo repeated cycles of abandonment and reactivation; and (6) a base-level lake system (Spillway Lake) dammed behind the terminal moraine. These elements have a distinct spatial distribution (Fig. 14a). Evidence for seasonal subglacial water storage is restricted to active parts of the glacier downglacier of crevasse fields, where surface water can be routed to the bed. Supraglacial channels occur where surface catchments and discharge are large enough to allow channel incision rates to outpace surface ablation rates. Thus, perennial channels only occur where the glacier surface is not broken up by crevasse fields or into small, closed basins. Perched ponds occur where the glacier surface is broken up into closed basins, where the overall gradient of the glacier is $<2.4^{\circ}$. The life cycle of perched ponds is governed by the location of englacial cut-and-closure conduits and the frequency of connection and blockage events. Sub-marginal conduits occur below both flanks of the glacier and transport water from supraglacial channels, intermittent drainage from perched ponds, and possibly the subglacial drainage system into Spillway Lake. The lake lies at the hydrologic base level of the glacier, and its extent reflects the surface elevation of the glacier relative to the spillway through the terminal moraine.

\section{Evolution of the drainage system}

In this section, we present evidence for changes in drainage system structure through time, including features visible in Corona images from 1964 and 1965, speleological observations, and repeat surveys of Spillway Lake since 1999.

\subsection{Supraglacial channels}

In 1964, a connected supraglacial drainage stream network was present on the eastern side of the main trunk above the junction with the $E$ branch $(10-8 \mathrm{~km}$ from the terminus, 4950-4920 $\mathrm{m}$ a.s.l.) (Fig. 15a). By 2010, this part of the glacier had been broken up into basins E-7, E-8, and E-9, part of the lateral trough systems described in Sect. 4.4. Stream channels were no longer present, although a number of isolated elongate ponds occupied depressions close to some of the original channel locations (Fig. 15b). The depressions have an overall reduction in elevation to the south, but in detail they have up-and-down long profiles. In cross profile, they are U-shaped and become wider and deeper through time (Fig. 15c).

We hypothesize that the supraglacial channels became deeply incised and transitioned into cut-and-closure conduits, which continue to evacuate meltwater below the glacier margins despite fragmentation of the surface topography. Channel incision may have been encouraged by thickening debris cover (from melt-out of englacial debris) that would have reduced glacier surface lowering rates.

At the distal end of the eastern lateral trough, conduit NG05 (Fig. 6) emerges into Spillway Lake. Passage morphology indicates that at this point the conduit formed by cut and closure (Sect. 3.2). Thus, there is evidence for a cut-and-closure 

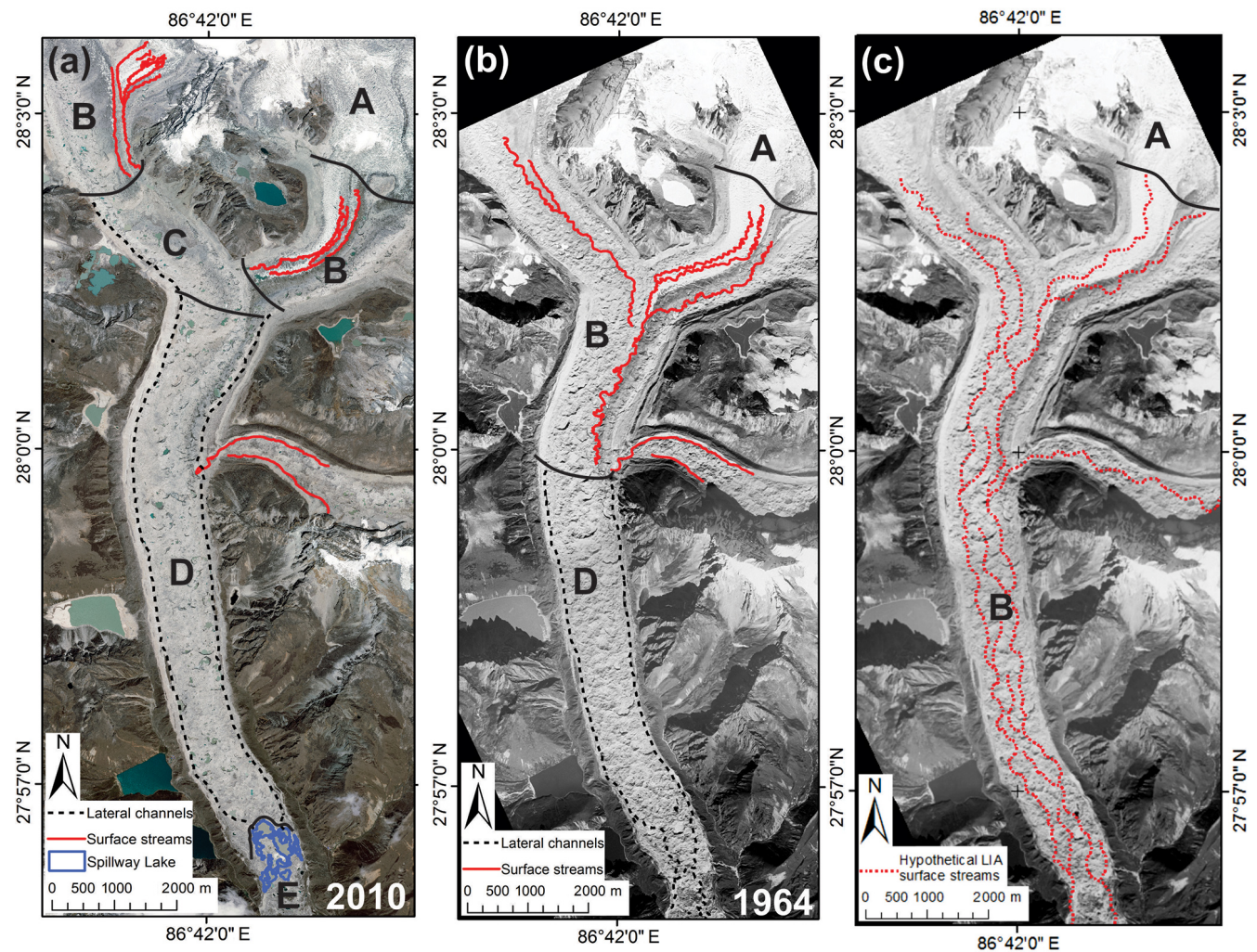

Figure 14. Zonation of the drainage system in (a) 2010 and (b) 1964, and (c) a hypothetical configuration at the Little Ice Age maximum. A: crevasse fields; B: supraglacial channels; C: transitional zone with shallow basins; D: closed surface basins with perched lakes; E: Spillway Lake. Dashed black lines indicate the positions of sub-marginal conduits.
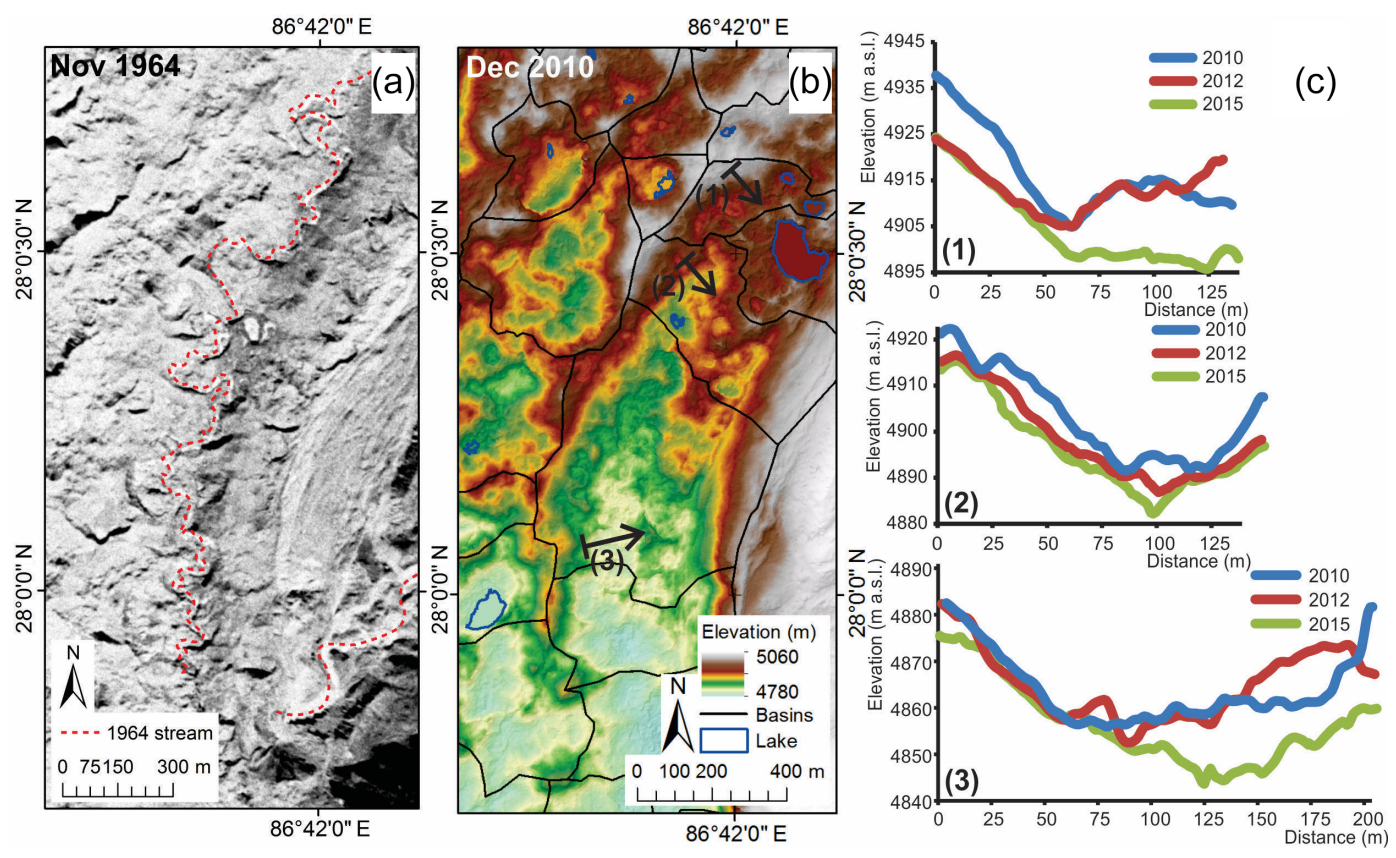

Figure 15. Evolution of the eastern margin of the main trunk of Ngozumpa Glacier, 1964-2015. (a) Supraglacial streams on the glacier surface in 1964 Corona imagery; (b) 2010 DEM, showing surface basins and the location of profiles; (c) surface profiles in 2010, 2012, and 2015, showing patterns of downwasting. 
origin of subsurface conduits at both ends of the eastern lateral trough. We therefore infer that the sub-marginal conduits originated as supraglacial streams that became incised below the surface. Such a scenario would require a continuous slope along both glacier margins. We conclude that supraglacial streams occurred along both margins before development of the current irregular topography, but transition to cut-andclosure conduits allowed these drainage routes to persist after break-up of the glacier surface.

\subsection{Englacial conduits in the hummocky debris-covered zone}

Transition of drainages from supraglacial channels to cutand-closure conduits appears to have been a widespread process on the glacier. The presence of sutures, planar voids, and bands of sorted sediments in the ceilings and walls of conduits NG-01-NG-05 record former episodes of channel incision. As was the case for the lateral channels, we infer that systems of supraglacial channels existed in the central part of the lower tongue before the glacier surface was broken up into small closed basins (Fig. 14c).

Differential surface ablation can eventually cause fragmentation and abandonment of cut-and-closure conduits, cutting off downstream reaches from former water sources. In abandoned reaches, processes of passage closure dominate over those of enlargement, and systems gradually shut down. Because cut-and-closure conduits are generally located close to the glacier surface, shut-down is commonly incomplete. Zones of narrow voids or sutures with infills of unfrozen sediment may persist, forming meandering lines of high permeability through otherwise impermeable glacier ice.

Reactivation of abandoned conduits will occur if a new water source becomes available, and a conduit remnant connects this source with a region of lower hydraulic potential. These conditions are met on stagnant, low-gradient glacier surfaces. Supraglacial ponds in closed basins provide both reservoirs of water and regions of elevated hydraulic potential. Drainage is highly episodic, and water may be stored in supraglacial ponds for years before passing farther down the system.

On the debris-covered part of Ngozumpa Glacier, cut and closure is the dominant primary process of conduit formation, and active and relict cut-and-closure conduits create a secondary permeability that can be exploited by water from supraglacial ponds. Debris-filled crevasse traces may provide additional lines of weakness in some cases, although this is likely a minor process. We have not observed hydrofracture-type conduits in the debris-covered area of Ngozumpa Glacier, although it is possible that they may form under compressive flow conditions as described on Khumbu Glacier by Benn et al. (2009). Hydrofracturing likely plays a dominant role in surface-to-bed drainage in the crevasse fields of the upper ablation zone.

\subsection{Spillway Lake}

The recent history of Spillway Lake was discussed in detail by Thompson et al. $(2012,2016)$ and is briefly reviewed here. The present spillway through the SW side of the terminal moraine has been in existence since at least 1965, when water emerged from the glacier and entered a small pond behind the lateral moraine (1; Fig. 13). In the following decades, the Spillway Lake system expanded upglacier from this point. On the Survey of Nepal (1996) map based on aerial photographs taken in 1992, the lake has a ribbon-like form, extending NE for $\sim 600 \mathrm{~m}$ from the spillway. The lake had essentially the same outline at the time of our first field survey in 1998, when water was observed to enter the lake via a subaerial portal and an upwelling point (Fig. 13; Benn et al., 2001; Thompson et al., 2012). Between 1998 and 1999, several chasms and holes opened up on the glacier surface north of the western portal, and by 2001 these had evolved into linear ponds and lakes (2; Fig. 13). Between 2001 and 2009, the Spillway Lake system underwent considerable expansion to the north, accompanied by upglacier migration of the portal locations (3, 4; Fig. 13).

The predominantly linear patterns of lake expansion, and the location of meltwater portals and upwellings, indicate that evolution of the Spillway Lake system was strongly preconditioned by the locations of shallow englacial conduits (a, b; Fig. 13). Conduit NG-05 (Sect. 3.4 and Fig. 6) and other examples exposed around the lake margins show that the drainage system consists of cut-and-closure conduits graded to lake level. This near-surface englacial conduit system provided pre-existing lines of weakness in the ice which, when opened up to the surface by internal ablation and collapse, were exploited by ice-cliff melting and calving processes.

Spillway Lake was thus established on a template provided by two englacial conduits (a, b, Fig. 13), which were confluent prior to 1992. As it expanded upglacier, Spillway Lake encroached on areas formerly occupied by perched ponds and incorporated former supraglacial basins. A recent example is basin C-33, which forms an inlier within the Spillway Lake catchment (Figs. 10a and 13). This basin contained a perched pond in 2009 and 2010, but this drained prior to December 2012 and has not reformed. It is likely that this basin will become entirely subsumed within the Spillway Lake catchment in the near future, as a consequence of icecliff backwasting.

\subsection{Changing drainage patterns on the glacier}

Comparison of the drainage system structure in 2010 with evidence in Corona imagery from 1964 shows an upglacier expansion of the area occupied by closed depressions and perched ponds, and the formation and upglacier expansion of the base-level Spillway Lake (Fig. 14b). The widespread occurrence of cut-and-closure conduits provides evidence of an even earlier stage in drainage evolution, when supraglacial 
channels extended along most of the glacier tongue and closed basins were absent or rare (Fig. 14c). The upglacier limit of supraglacial channels was similar in 1964 and 2010, due to the persistent location of crevasse fields in the upper ablation zone. The channels are likely to have had similar upglacier limits in earlier times, because of the strong topographic control of the crevasse fields. Figure $14 \mathrm{c}$ shows a hypothetical distribution of supraglacial channels on the glacier during the Little Ice Age and early 20th century.

Ngozumpa Glacier has thus responded to a prolonged period of negative mass balance with a systematic reordering of its drainage system, characterized by less efficient evacuation of meltwater and greater amounts of storage. More recent elements of the drainage system retain a memory of older elements, and processes and patterns of ablation on the glacier continue to be influenced by active and relict channels and conduits. Former supraglacial channels preconditioned the location and density of cut-and-closure conduits, which in turn precondition the formation and drainage of perched ponds and provide templates for the expansion of Spillway Lake.

\section{Comparison with other debris-covered glaciers}

Observations on other debris-covered glaciers in the Himalaya indicate that their drainage systems share many of the characteristics described in this paper. Seasonal velocity fluctuations have been documented on other large glaciers in the Mount Everest region and on Lirung Glacier, Nepal (Benn et al., 2012; Kraaijenbrink et al., 2016), indicating surfaceto-bed drainage and variations in subglacial water storage. Perennial supraglacial channels occur in the upper ablation zones of many glaciers, in places where catchments are not fragmented by crevasse fields or irregular surface topography (Gulley et al., 2009b; Benn et al., 2012). Continuity between a supraglacial channel and an englacial cut-and-closure conduit has been observed on Khumbu Glacier, clearly demonstrating the genetic relationship between the two features (Gulley et al., 2009b). Perched ponds are widespread on Himalayan debris-covered glaciers, and evidence for repeated filling and drainage (Watson et al., 2016; Miles et al., 2017) suggests that englacial conduits may play an important role in their life cycles. However, englacial conduits have only been explored in a few glaciers (Gulley and Benn, 2007; Gulley et al., 2009b; Benn et al., 2009), and much research remains to be done. Similarly, very little is known about possible sub-marginal channels in Himalayan glaciers, and our few attempts to enter these highly dynamic environments have been repulsed.

The upglacier expansion of the area occupied by closed depressions and perched ponds on Ngozumpa Glacier (Fig. 14) also appears to have occurred on other glaciers in the Everest region during the current period of negative mass balance. Iwata et al. (2000) noted an increase in the area occupied by high-relief hummocky topography on Khumbu Glacier from 1978 to 1995. The presence of cut-and-closure conduits below hummocky terrain on that glacier shows that these areas formerly supported supraglacial streams (Gulley et al., 2009b).

There is strong evidence on many glaciers that growth of base-level lakes is preconditioned by englacial conduits. For example, upglacier expansion of the proglacial lake at Tasman Glacier, New Zealand, has repeatedly followed the location of former chains of sink holes on the glacier surface (Kirkbride, 1993; Quincey and Glasser, 2009). Recently formed chains of ponds in the lower ablation zone of Khumbu Glacier strongly suggest that the same process is underway on that glacier (Watson et al., 2016). The integrated picture of drainage system structure and evolution presented in this paper provides a framework for predicting what the future may have in store for other debris-covered glaciers in the region.

\section{$7 \quad$ Summary and conclusions}

This paper has provided the first synoptic interpretation of the drainage system of a Himalayan debris-covered glacier, including the spatial distribution of system components, their evolution through time, and their influence on processes and patterns of ablation. Our specific conclusions are as follows.

1. In the upper ablation zone, seasonal variations in ice velocity indicate routing of surface meltwater to the bed via crevasses and fluctuations in subglacial water storage.

2. Systems of supraglacial channels occur where the glacier surface is uninterrupted by crevasses or closed depressions, allowing efficient evacuation of surface melt.

3. Active sub-marginal channels are evidenced by linear zones of subsidence along both margins of the glacier and by fluctuations in surface water storage and release. These channels likely formed from supraglacial channels by a process of cut and closure, and they permit long-distance transport of meltwater through the ablation zone. Transport of sediment via the lateral channels destabilizes inner moraine flanks and delivers debris to the terminal zone, where it modulates ablation processes.

4. In the lower ablation zone (below $\sim 5000 \mathrm{~m}$ ) the glacier surface consists of numerous closed drainage basins. Meltwater in this zone typically undergoes storage in perched ponds before being evacuated via the englacial drainage system. Englacial conduits in this zone evolved from supraglacial channels by a process of cut and closure, and they may undergo repeated cycles of abandonment and reactivation. Cut-and-closure is the dominant 
process of conduit formation on Ngozumpa Glacier and is likely so on other debris-covered glaciers in the Himalaya.

5. Enlargement of englacial conduits removes ice mass that is not captured by surface observations until conduit collapse occurs, with the implication that observations of sudden surface lowering need not reflect sudden glacier mass loss over the same time period. Subsurface processes play a governing role in creating, maintaining, and shutting down exposures of ice at the glacier surface, with a major impact on spatial patterns and rates of surface mass loss.

6. A large lake system (Spillway Lake) is dammed behind the terminal moraine, which forms the hydrologic base level for the glacier. Since the early 1990s, Spillway Lake has expanded upglacier, exploiting weaknesses formed by englacial conduits.

7. As part of the glacier response to the present ongoing period of negative mass balance, the structure of the drainage system has changed through time, characterized by decreasing efficiency and greater volumes of storage. Processes and patterns of ablation on the glacier are strongly influenced by active and relict elements of the drainage system. Former supraglacial channels evolved into cut-and-closure conduits, which in turn precondition the formation and drainage of perched ponds and provide templates for the expansion of Spillway Lake. Thus drainage elements that initially formed during earlier active phases of the glacier's history continue to influence its evolution during stagnation.

Data availability. Supplementary data are available at https://doi. org/10.1594/PANGAEA.880056 (Benn et al., 2017). The data include GeoTiffs of orthophotos and DEMs covering the debriscovered part of Ngozumpa Glacier in 2010, 2012, and 2015, and the velocity data on which Fig. 10 is based.

Competing interests. The authors declare that they have no conflict of interest.

Acknowledgements. Funding for Sarah Thompson was provided by the European Commission FP7-MC-IEF grant PIEF-GA2012-330805, and for Lindsey Nicholson by the Austrian Science Fund (FWF) Elise Richter Grant (V309-N26). Financial support for fieldwork in 2009 was provided by the University Centre in Svalbard and a Royal Geographical Society fieldwork grant to Sarah Thompson. Field assistance was given by Annelie Bergström and Alison Banwell. TerraSAR-X data were kindly provided by the German Aerospace Center (DLR) under project HYD0178. The meteorological data were collected within the Ev-K2-CNR SHARE Project, funded by contributions from the Italian National
Research Council and the Italian Ministry of Foreign Affairs, and we thank Patrick Wagnon of the Institut de Recherche pour le Développement, France, for collecting and releasing the 2014-2015 data used in this paper. Careful and constructive reviews by Akiko Sakai and Duncan Quincey are gratefully acknowledged.

Edited by: Andreas Vieli

Reviewed by: Duncan Quincey and Akiko Sakai

\section{References}

Benn, D. I., Wiseman, S., and Hands, K.: Growth and drainage of supraglacial lakes on the debris-mantled Ngozumpa Glacier, Khumbu Himal, J. Glaciol., 47, 626-638, 2001.

Benn, D. I., Gulley, J., Luckman, A., Adamek, A., and Glowacki, P.: Englacial drainage systems formed by hydrologically driven crevasse propagation, J. Glaciol., 55, 513-523, 2009.

Benn, D. I., Bolch, T., Dennis, K., Gulley, J., Luckman, A., Nicholson, K.L., Quincey, D., Thompson, S., Tuomi, R., and Wiseman, S.: Response of debris-covered glaciers in the Mount Everest region to recent warming, and implications for outburst flood hazards, Earth Science Reviews, 114, 156-174, 2012.

Benn, D. I., Thompson, S., and Luckman, A.: Surface topography and velocities of Ngozumpa Glacier, Nepal, with links to GeoTIFFs, PANGAEA, https://doi.org/10.1594/PANGAEA.880056, 2017.

Bolch, T., Buchroithner, M., Pieczonka, T., and Kunert, A.: Planimetric and volumetric glacier changes in the Khumbu Himal, Nepal, since 1962 using Corona, Landsat TM and ASTER data, J. Glaciol., 54, 592-600, 2008a.

Bolch, T., Buchroithner, M. F., Peters, J., Baessler, M., and Bajracharya, S.: Identification of glacier motion and potentially dangerous glacial lakes in the Mt. Everest region/Nepal using spaceborne imagery, Nat. Hazards Earth Syst. Sci., 8, 13291340, https://doi.org/10.5194/nhess-8-1329-2008, 2008b.

Bolch, T., Pieczonka, T., and Benn, D. I.: Multi-decadal mass loss of glaciers in the Everest area (Nepal Himalaya) derived from stereo imagery, The Cryosphere, 5, 349-358, https://doi.org/10.5194/tc-5-349-2011, 2011.

Clayton, L.: Karst topography on stagnant glaciers, J. Glaciol., 5, 107-112, 1994.

Fountain, A. G. and Walder, J.: Water flow through temperate glaciers, Rev. Geophys., 36, 299-328, 1998.

Gulley, J. and Benn, D. I.: Structural control of englacial drainage systems in Himalayan debris-covered glaciers, J. Glaciol., 53, 399-412, 2007.

Gulley, J., Benn, D. I., Screaton, L., and Martin, J.: Mechanisms of englacial conduit formation and implications for subglacial recharge, Quaternary Sci. Rev., 28, 1984-1999, 2009a.

Gulley, J., Benn, D. I., Luckman, A., and Müller, D.: A cut-andclosure origin for englacial conduits on uncrevassed parts of polythermal glaciers, J. Glaciol., 55, 66-80, 2009b.

Horodyskyj, U. N.: Contributing factors to ice mass loss on Himalayan debris-covered glaciers, unpublished $\mathrm{PhD}$ thesis, University of Colorado at Boulder, 183 pp., 2015.

Iwata, S., Aoki, T., Kadota, T., Seko, K., and Yamaguchi, S.: Morphological evolution of the debris cover on Khumbu Glacier, Nepal, between 1978 and 1995, in: Debris-Covered Glaciers, 
Proceedings of a workshop held at Seattle, Washington, USA, September 2000, edited by: Nakawo, N., Fountain, A., and Raymond, C., IAHS Publ. no. 264, 3-11, 2000.

Jarosch, A. H. and Gudmundsson, M. T.: A numerical model for meltwater channel evolution in glaciers, The Cryosphere, 6, 493503, https://doi.org/10.5194/tc-6-493-2012, 2012.

Kääb, A., Berthier, E., Nuth, C., Gardelle, J., and Arnaud, Y.: Contrasting patterns of early twenty first century glacier mass change in the Himalayas, Nature, 488, 495-498, 2012.

Kirkbride, M. P.: The temporal significance of transitions from melting to calving termini at glaciers in the central Southern Alps of New Zealand, The Holocene, 3, 232-240, 1993.

Kraaijenbrink, P., Meijer, S. W., Shea, J. M., Pellicciotti, F., De Jong, S. M., and Immerzeel, W. W.: Seasonal surface velocities of a Himalayan glacier derived by automated correlation of Unmanned Aerial Vehicle imagery, Ann. Glaciol., 57, 103-113, 2016.

Krüger, J.: Glacial processes, sediments, landforms, and stratigraphy in the terminus region of Myrdalsjökull, Iceland, Folia Geographica Danica, 21, 1-233, 1994.

Luckman, A., Quincey, D. J., and Bevan, S.: The potential of satellite radar interferometry and feature tracking for monitoring flow rates of Himalayan glaciers, Remote Sens. Environ., 111, 172181, https://doi.org/10.1016/j.rse.2007.05.019, 2007.

Mertes, J. R., Thompson, S. S., Booth, A. D., Gulley, J. D., and Benn, D. I.: A conceptual model of supraglacial lake formation on debris-covered glaciers based on GPR facies analysis, Earth Surf. Proc. Land., 42, 903-914, https://doi.org/10.1002/esp.4068, 2016.

Miles, E. S., Pellicciotti, F., Willis, I. C., Steiner, J. F., Buri, P., and Arnold, N. S.: Refined energy-balance modelling of a supraglacial pond, Langtang Khola, Nepal, Ann. Glaciol., 57, 29-40, 2015.

Miles, E., Willis, I., Arnold, N., Steiner, J., and Pellicciotti, F.: Spatial, seasonal and interannual variability of supraglacial ponds in the Langtang Valley of Nepal, 1999-2013, J. Glaciol., 63, 85105, 2017.

Nicholson, L. A.: Modelling melt beneath supraglacial debris: Implications for the climatic response of debris-covered glaciers, PhD thesis, University of St Andrews, UK, 2004.

Nicholson, L. and Benn, D. I.: Properties of natural supraglacial debris in relation to modelling sub-debris ice ablation, Earth Surf. Proc. Landf., 38, 490-501, 2012.
Quincey, D. J. and Glasser, N. F.: Morphological and ice-dynamical changes on the Tasman Glacier, New Zealand, 1990-2007, Global Planet. Change, 68, 185-197, 2009.

Quincey, D. J., Richardson, S. D., Luckman, A., Lucas, R. M., Reynolds, J. M., Hambrey, M. J., and Glasser, N. F.: Early recognition of glacial lake hazards in the Himalaya using remote sensing datasets, Global Planet. Change, 56, 137-152, 2007.

Quincey, D., Luckman, A., and Benn, D. I.: Quantification of Everest-region glacier velocities between 1992 and 2002 using satellite radar interferometry and feature tracking, J. Glaciol., 55, 596-606, 2009.

Richardson, S. D. and Reynolds, J. M.: An overview of glacial hazards in the Himalayas, Quatern. Int., 65-66, 31-47, 2000.

Sakai, A., Nakawo, M., and Fujita, K.: Melt rates of ice cliffs on the Lirung Glacier, Nepal Himalaya, 1996, Bulletin of Glacier Research, 16, 57-66, 1998.

Sakai, A., Takeuchi, N., Fujita, K., and Nakawo, M.: Role of supraglacial ponds in the ablation process of a debris covered glacier in the Nepal Himalayas, in: Debris-Covered Glaciers, Proceedings of a workshop held at Seattle, Washington, USA, September 2000, IAHS Publ. no. 264, 119-130, 2000.

Sakai, A., Nishimura, K., Kadota, T., and Takeuchi, N.: Onset of calving at supraglacial lakes on debris covered glaciers of the Nepal Himalaya, J. Glaciol., 55, 909-917, 2009.

Survey of Nepal: 1:50,000 Topographical Map Sheet 2786 03: Namche Bajar, Survey Department, Ministry of Land Reform and Management, Kathmandu, 1996.

Thompson, S., Benn, D. I., Dennis, K., and Luckman, A.: A rapidly growing moraine dammed glacial lake on Ngozumpa Glacier, Nepal, Geomorphology, 145-146, 1-11, 2012.

Thompson, S., Benn, D. I., Mertes, J., and Luckman, A.: Stagnation and mass loss on a Himalayan debris-covered glacier: processes, patterns and rates, J. Glaciol., 62, 467-485, 2016.

Watson, C. S., Quincey, D. J., Carrivick, J. L., and Smith, M. W.: The dynamics of supraglacial ponds in the Everest region, central Himalaya, Global Planet. Change, 142, 14-27, 2016.

Yamada, T.: Glacier lake and its outburst flood in the Nepal Himalaya, Data Centre for Glacier Research, Japanese Society of Snow and Ice, Japan, Monograph No. 1, 96 pp., 1998. 